\title{
دور المعاهد التعليمية الخاصة بمحافظة الدقهلية في تلبية متطلبات سوق العمل
}

\section{وفاء سماحه مخمدر رزق عوضن}

لتحقيق هذه التتمية الاقتصادية و الاجتماعيــة

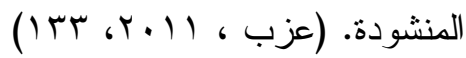

ورغم الجهود التي بذلت من قبـــل الدول و الحكومات لإحـــاث الثقـــارب بــين

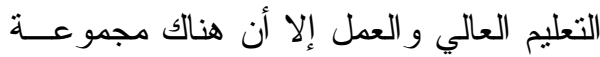

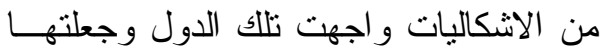
عاجزة عن تحقيق هذا التقارب في كثير من الاحيان، ومن هذه الاشكاليات ظهور مهـن فئن

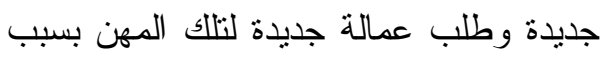

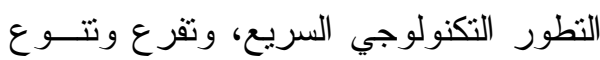
التخصصات الموجودة داخل قطاعات العمل و التي تتغير باستمرار بسبب التقدم العلمـي

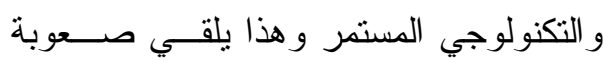
على التعليم العالي فـــي إحــــاث التقـــارب

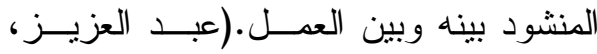
$(\varepsilon r T, r+) \leqslant$ وفي محاولة لتحسين أوضاع التعـــيم بالجامعات المصرية و إتاحة فــرص التعلــيم العالي لأكبر عدد ممكن من الطلاب وتقـــيم تعليم عالي متميز فتحت مصر البــاب أمسـام

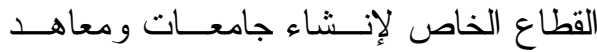
خاصة بمصروفات تعمل جنبا إلى جنب مع
إن التحديات التي نعيشها في القــرن

الحادي و العشرين، فرضت على المؤسسات باختلاف أنثكالها مو اكبة تلك التحديات، وذللك بتطوير وتغيير أنظمتها الاداريــة وابتكــار

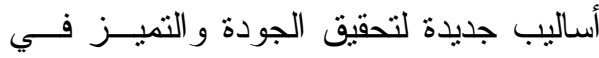
الاعمال، خـصوصـا فــي ظــل المنافـسة الاقتصـادية الثنديدة التي يعيشها العالم اليــوم و التحول نحو افتصاد المعرفة.

و المؤسسات التعليمية بصفتها أنظمــة

مفتوحة فهي تتأثز بتلك المتغير ات المحيطــــة بها وتتفاعل معها وبالتالي فهي مطالبة أكثر

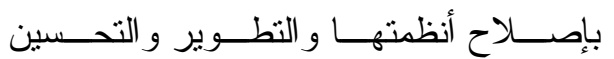
المستمر و التمبز في الاداء وذللك للحـصول على مخرجات ذات كفـــاءة عاليــة وفاعلـــة وقادرة على الابتكار وتحقيق متطلبات سوق العمل، ومن الممكن تحقيق ذلك عن طريـق إحداث التقارب بين التعليم و العمل ويأتي هذا التقارب بين التعليم و العـــل مــن منطلــق العلاقة بين التعلــيم و التتميــة الاقتــصادية و الاجتماعية و التي تفــرض علــى التعلــيم ضرورة إعداد المـــوارد البـشرية اللازمـــة 
حديثة تنو افق مــع ســـوق العدـلـ المتغيـــر

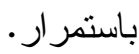

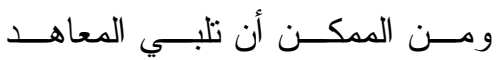

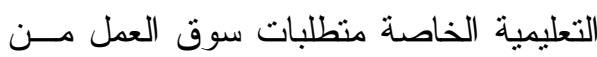
خلال تفعيل الأنشطة الطلابية بها ، مــرورا

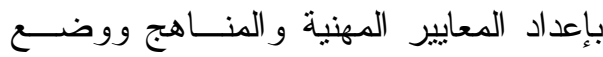
السياسات و الاستر اتيجيات وتدريب المدربين و الاشتر الك بالإدارة وتقييم الخرجين وصــولا

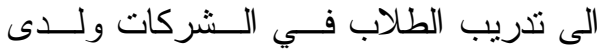
أصحاب الأعمال و المؤسسة التعليمية، فجميع

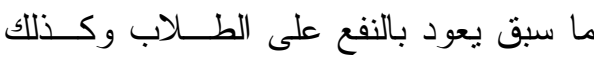
المعاهد التعليمية الخاص وسوق العمل حيث تزيد مهارة الطالب وتساعده في إيجاد فرص عمل أفضل بعد تخرجه ، و يستفيد أصحاب

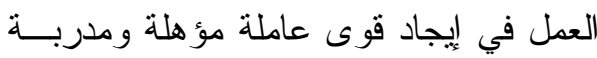

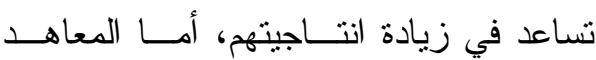
التعليمية فتستقيد في إثز اء مناهجها وتضمينها أحدث المعلومات و المعارف و هـــي بالتــالي

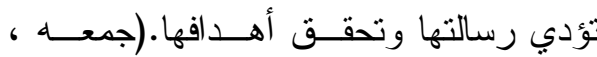
(No, r.) r

مشكلة الدراسة : - مان

ان الاهتمام بــالتعليم ودعــم وادارة مدخلاته للوصول الى مخرجات ذات فاعلية

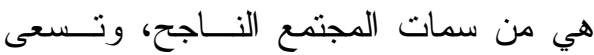
الثر اكة بين التعليم وسوق العمل الى تحقيق التكامل بينهم لتحقيق أهداف الطرفين، ولكنه حتى الأن لا توجد شر اكه حقيقية فاعلة بـين لين
الجامعات الحكومية بهذف إتاحسـة الفــرص لر أس المال الوطني أن يستثمر جنبـــا مــن لـن

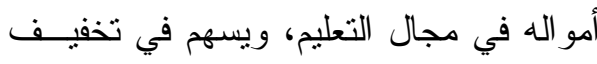

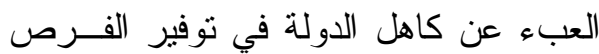
التعليمية على المستوى الجامعي. وترتب على ذلك تعدد أثنكال التعلــيم العالي في مصر فمنهـــا التعلــيم الحكـــومي لعي و التعليم غير الحكومي الذي ظهر في عـدة فئ أثنكال منها الجامعات الخاصة و الجامعــات

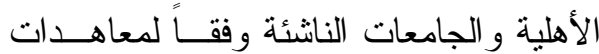

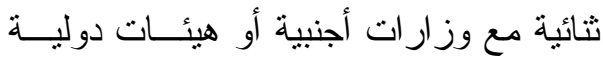

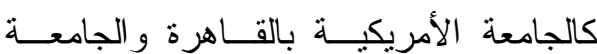
العربية المفتوحة و الأكاديمية العربية البحرية

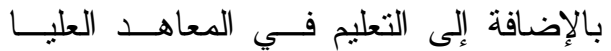

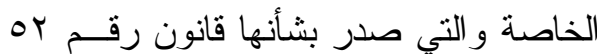

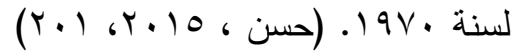

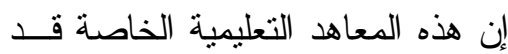
زادت في الفترة الاخيرة وز اد عددها وعـدـد الطلاب المنتمين، ومن ثم كان عليها تأسيس

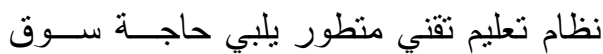
العمل ويساعد على النمو الاقتصادي، وجذب لفي لفي

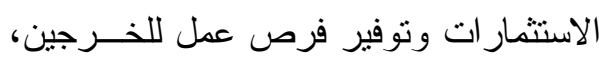
و لا يمكن أن يتحقق ذلك إلا من خلال تفعيل

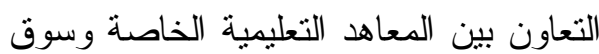

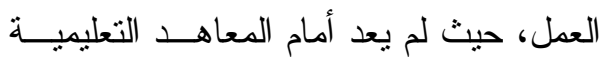

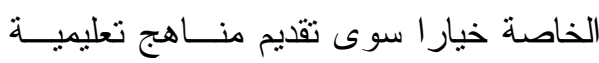




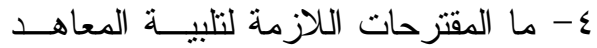

التعليمية الخاصــة لمتطلبــات ســوق

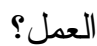

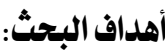

يتمثل الهرف الرئيسي للبحــث فــي

وضع تصور مقترح للتظلب على معوقـات

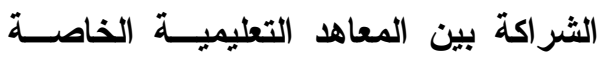

وسوق العمل وذلك من خلال :

1- التعرف على الفلسفة الحاكمة للمعاهــــ

التعليمية الخاصة.

r- تحديد متطلبات سوق العمل من المعاهد

التعليمية الخاصة.

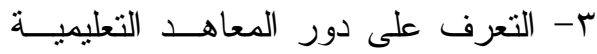

الخاصة بمحافظة الدقهليــة فـــي تلبيــة

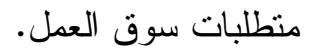

ـ- التوصل الى تـصور مقتــرح لــدور

المعاهد التعليمية الخاصـــة فــي تلبيــة

منطلبات سوق العمل.

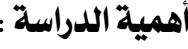

إن تلبية المعاهد التعليميــة الخاصـــة

لمتطلبات سوق العمل مــن الموضــوعات

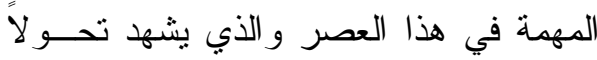

كبير اً في جميع جو انب الحياة، وهذا التحول

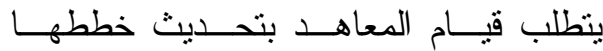

ومناهجها و أهدافها لمواجهة التغير ات التـي لئي

تحدث في المجتمع وتلبية منطلبــات ســوق

العمل لذا جاءت أهمية الدر اسة متمتلة في :
المعاهد التعليمية الخاصة وسوق العمل على الرغم من التوسع في انثاء المعاهد التعليمية الخاصة و التي شهدتها مــصر فـــي العقــود

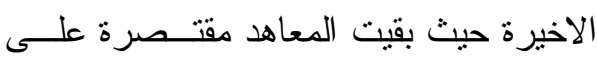
استيعاب الاعداد المتزايدة من الطلاب الذين

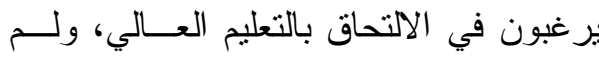
يو اكب ذلك التوسع تحسين ملحوظ في نوعية

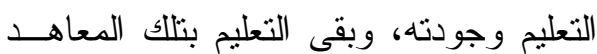
محافظا على الاساليب التقليدية ســـواء مــن ونـ

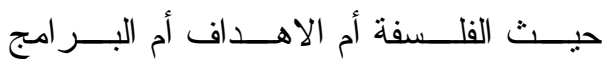
و الاساليب ونظم الثقويم و غير ها.

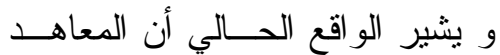
التعليمية الخاصة لا تــــلي أهميــة كبيــرة للتتسيق مع سوق العمل وتتبـــع احتياجاتـهـ، وبنفس الوقت فإن قطاع العمل لم يكن فعـالا في كسر هذه العزلة، ويرجع ذللك الى عـدم تفعيل التعاون بينهما. ومن هنا كانت مشكلة الدر اسة و التي يمكن صياغتها في التساؤلات

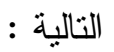

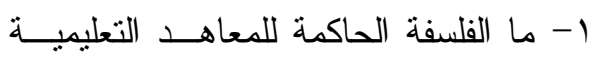

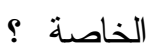

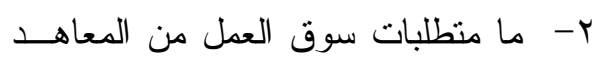

$$
\text { التعليمية الخاصة ؟ ملطبات }
$$

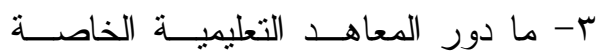
بمحافظة الدقهلية في تلبيــة منطلبــات

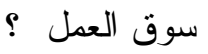




\section{منهج الدراسة:}

لتحقيق أهداف الدراسة سوف تستخدم

الدراسة المنهج الوصفي الذي يعتمـــد علـى

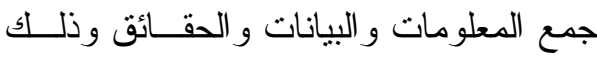

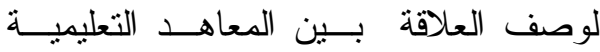

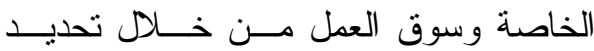

الفلسفة الحاكمة للمعاهد التعليميـــة الخاصـــة

ومعرفة متطلبات سوق العمل و وتحديــد دور

المعاهد التعليمية الخاصة في تلبية منطلبــات

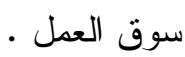

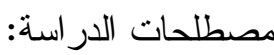

(1) المعاهد التعليمية الخاصة

مؤسسات تعليمية تقبل طلابهـــا مسن

الحاصلين على الثانوية العامة أو ما بعادلهــا

ومدة الدارسة بها أربع سنوات ويقوم بإنشائها

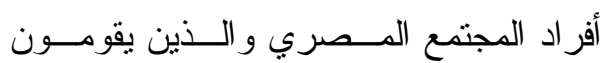

باستثمار أمو الهم فيها كأفراد أو على شـــل شركات أهلية استثمارية مساهمة وبالتتـسـيق مع بعض مؤسسات التعليم العالي العربية أو

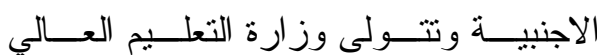

الإشر اف عليها.

(Y) (Y) سوق العمل:

يعرف سوق العمل على أنه "المكان

الذي تثقابل فيه مختلف العوامل التي تــؤثز في حالة التوظيف و الذي يبحث فيه أربــاب

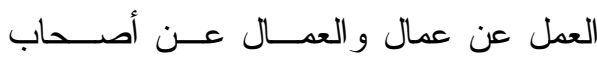

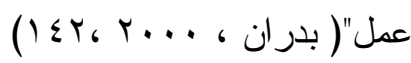

ا- أن البحث يتتاول موضوع فــي غايــة

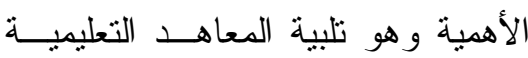

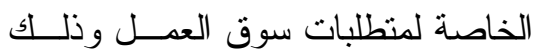
للحــــصول علــــى مخرجــــــات ذات كفاءة عاليـــة وفاعلــة وقـــادرة علــى الابتكار وتحقيقـي متطلبــات التتميــة الشاملة.

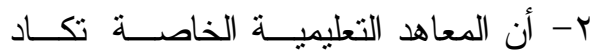

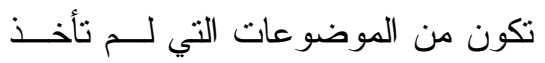
حقها من البحث و الدر استة وخــصوصاً في إطار ربطها بسوق العمل وقد يكون هذا البحث محاولة لسد هذه الثغرة. r- أن هذه الدراسة تمنل نلبية لما أوصـــت به الكثيــر مــن الدراســات الــسابقة بضرورة ايجاد شــر اكه حقيقيــة بــين المعاهد التعليمية الخاصة وسوق العمل. ؟- مساعدة المسئولين عن المعاهد التعليمية الخاصة في التعرف على اهم مشكلات خريجي المعاهد التعليمية الخاصة فـي مجال سوق العمل. 0- أن نتائج هذه الدر اسة يمكن الاســتفادة منها في رصد مؤشرات كفاءة خريجي

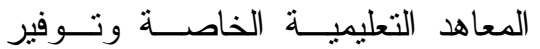
إطار متكامل لفحص حركة المخرجات إلى سوق العمــل وثرشــيد سياســات

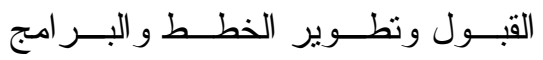

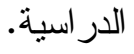


كل من مصر وكوريا والمــدخل التحليلـي

المقارن لتحليل انعكاسات الضغوط المحليـــة و الدولية المــؤثرة علــى أوضــــاع التعلــيم و التذريب وسوق العمل.

وقد توصلت الدراسة إلى مجموعـة مـنـ

$$
\text { النتائج منها : وتوصن }
$$

- إعطاء طابع أكبر من الاهتمام للار اسات

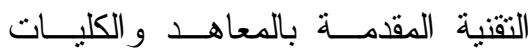

$$
\text { الجامعية. }
$$

- ربط مدرسة ثانويــة فنيــة بالــشركات الانتاجية العاملة في كل اقليم على حدة لـانه

$$
\text { حسب نوع النشاط السائد. }
$$

- قيام المعاهد و الكليات الجامعية بتــوفير لون

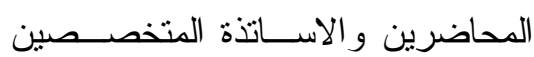

لتقديم الخدمات الاكاديميــة و المهنيـــة

$$
\text { للدارسين }
$$

- انثر الك القطاع الخاص في توفير الـــــم

المطلوب في زيادة فاعلية هذة الثر اكة.

r - دراسة (حسن، • 1 + ب) بعنوان التعليم

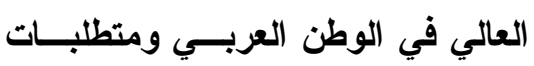

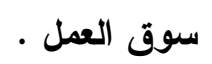

توضيح التحديات العالمية و المحليـــة

التي تواجه الجامعات العربية وتحديد الطريق

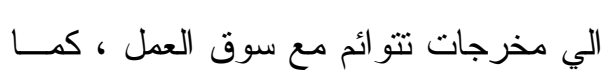

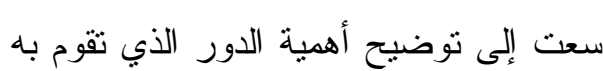

\section{الدراسات السابقة :}

تمكنت الباحثة من الاطلاع على عدد

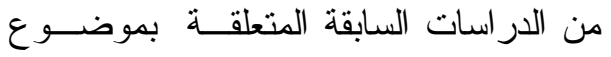
الدر اسة الحالية وهي : الاست

أولا: الدراسات العربية:

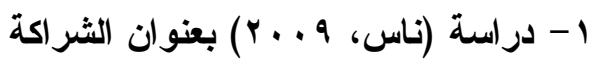
بين التعليم والتدريب وســوق العـــل

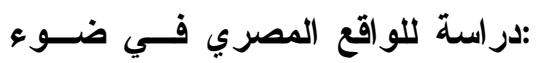
الخبرة الكورية.

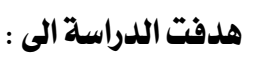
- توضيح التحديات و الضغوط التي تـدفع

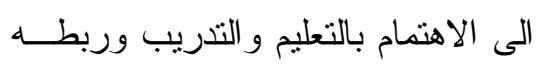
بسوق العمل في الوقت الر اهن.

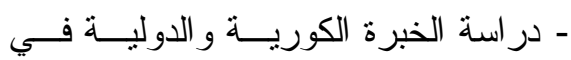
مجال ربط مؤسسات التعليم و التــدريب وله بسوق العمل.

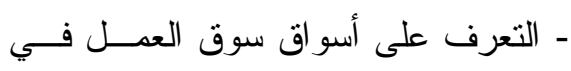
- التعرف على طبيعة الثر اكة بين التعليم

$$
\text { و التذريب وسوق العمل في مصر . }
$$

- توضيح بعض المقترحات التي قد تسهر

في زيادة الثر اكة بين التعليم والتنريب وسوق العمل لخدمة أغر اض التتمية في ولئ

$$
\text { المجتمع المصري. }
$$

وقد اعتمدت الدراسة في منهجها على

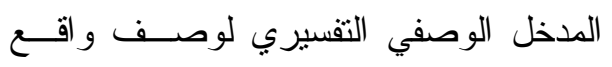
التعليم و التدريب و علاقتهما بسوق العمل في لوحي لوحي 


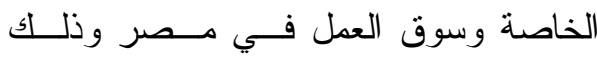

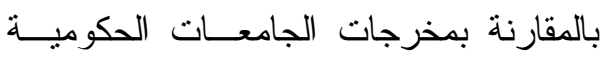

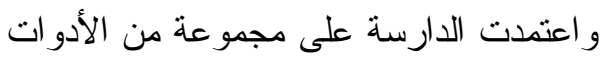

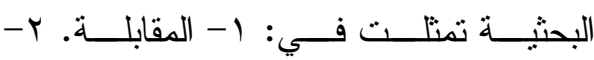

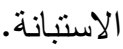

\section{وتوصلت الار اسة إلى:}

- بعد الربط بين مخرجات التعليم العـالي

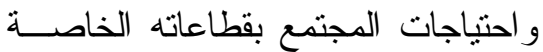

و العامة مشكلة عالمية تواجـهـ جميـع

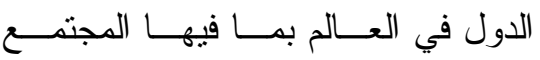

المصري تتهافت على مخرجات التعليم

العالي باتت نلوم مؤسسات التعليم العالي

على مخرجاتها.

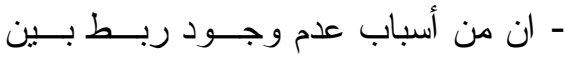

التعليم الجامعي وسوق العمل يرجع إلى

عدة أسباب منها عدم وجود معلومسـات

دقيقة عن الاحتياجات الفعليــة لــسوق

العمل وسرعة تغير احتياجـات ســوق

العمل وبطء استجابة مؤسسات التعلــيم

العالي لهذا التغيـــر و العمالـــة الأجنبيـــة

$$
\text { الرخيصة نسبياً. }
$$

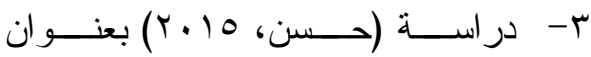

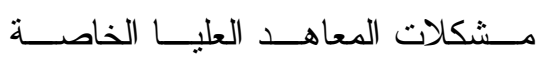

بجمهورية مصر العربيــة - دراســـة

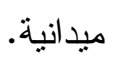

هدفت الدر اسة إلى الوقوف على مدى

كفاءة المعاهد العليا الخاصة مــن النــاحتين
مؤسسات المجتمع المدني في دعم وظــائف

التعليم العالي.

وقد توصلت الاراسة إلى مجموعــة مـنـ

النتائج منها:

- أن هناك مجموعة من التحـديات التــي

تو اجه التعليم العالي العربي منل العولمة

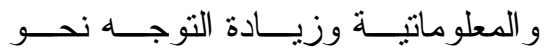

الخصخصة و المنافسة العالمية.

- ان تطبيق ادارة الجودة الـشاملة هـي

ضمان لمخرجــات تتــو ائم وحاجــات

المجتمع موضحا مبررات وفو ائد تطبيق

ادارة الجودة الـشـاملة فــي مؤسـسـات فئس

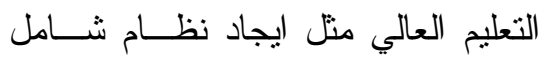

لضبط الجودة في الجامعات و الارتقـــاء

بـــستوى الاداء الاكـــاديمي بــصورة

مستمرة.

- هناك أدو ار لمؤسسات المجنمع المــدني

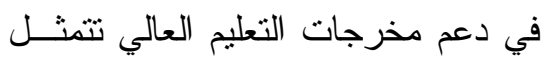

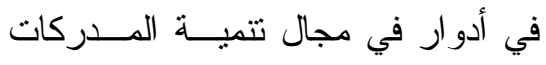

و القيم الاقتصادية و أدوار في مجال نتمية لتهية

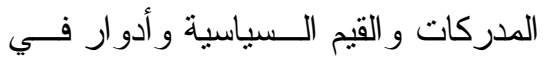

مجال تتمية المدركات و القيم البيئة.

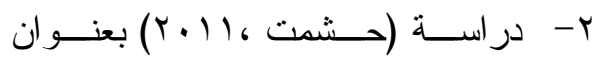

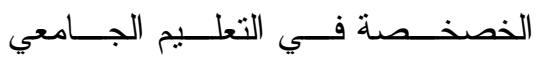

ومنطلبات سوق العمل .

هدفت الدر اسة إلى التعـرف علـى

نوعية العلاقة بــين مخرجـات الجامعــات 
ثانيا : الدراسات الاجنبية:

1- دراسة (yingxia,2000)

بعنوان" التعليم العالي الخاص وسوق

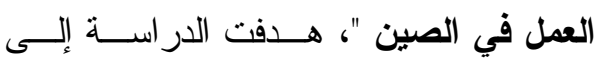

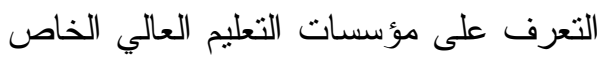

في الصين وربطها بسوق العمل.

ولقد اســتخدمت الدراســة المــنهج

الوصفي لوصــف وجمــع البيانـات عـن

مؤسسات التعليم العالي الخاص في الــصين لــين

وتحليلها في ضو ء احتياجات سوق العمل.

$$
\text { وتوصلت الدراسة إلى: }
$$

- أن وفرة مؤسسات التعليم العالي الخاص

$$
\text { تسنو عب الطلب على سوق العمل. }
$$

- إن مؤسسات التعليم العالي الخاص تعتبر

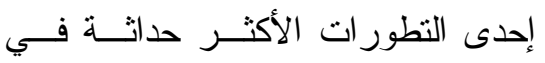

تشكيل الصورة في التعليم العسال فـي النسي

$$
\text { الأزمنة الأخيرة. }
$$

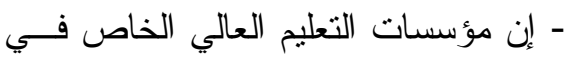

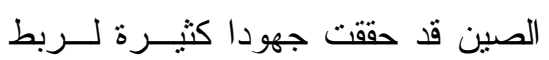

التعليم العالي بسوق العمل وان جهودها

يستو عبها سوق العمل و الخرجين.

ץ- دراسة دلون (Dhillon (2007)

هدفت الدر اسة التعـرف عافـى دور

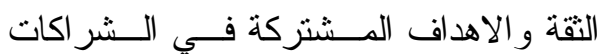

التعليمية بين المنظمات التعليمية في انجلترا،

وقد استخدم الباحث الملاحظــات الخاصـــة

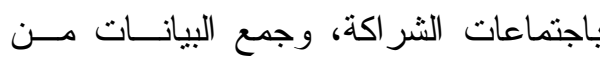

الكمية و الكيفية و التعرف على الواقع العـالي

لإدارة المعاهد العليا الخاصة بمصر وكــــللك

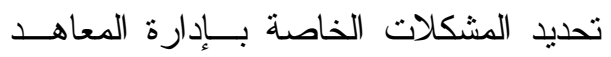
العليا الخاصة بمصر من وجهة نظر عينـــة

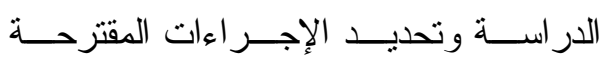

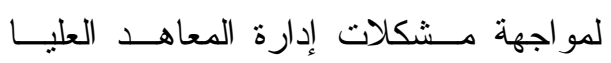

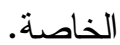

$$
\text { وتوصلت الاراسة إلى: }
$$

- إعادة النظر في صياغة أهداف المعاهد

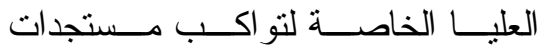

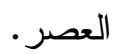

- أن تر اعي إدارة المعاهد العلي الخاصـــة

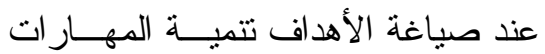
اللازمة للتعامل مع متغير ات العصر . - أن يكون القبول بنلك المعاهد فــي فئسي

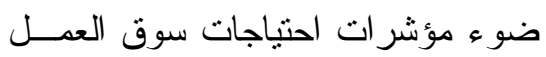

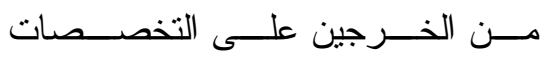

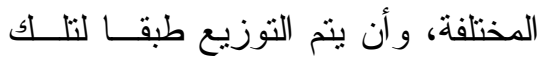
الاحتباجات.

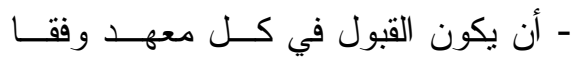

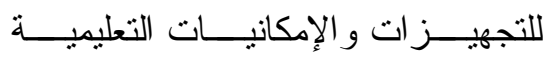

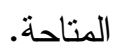
- أن تز اعي إدارة المعاهد العليا الخاصـــة

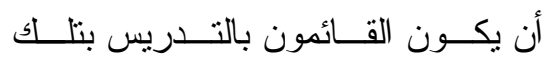
المعاهد على در اية كافية بأبعـاد نظــام

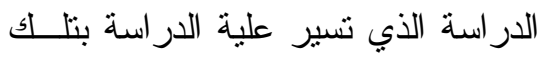

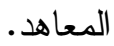


وقد أوصت الدراسة بأهمية تحقيـق

التكامل بين التكنولوجيا و العملية التعليمية في بلديه المدارس وضرورة اعداد بر امج هيكلة اعداد

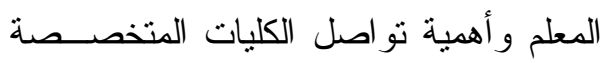
بإعداد المعلم مع المدرسين أثتـــاء الخدمـــة

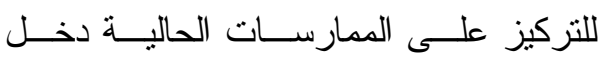
الصفوف ثانيا : الاطار النظري للاراسة :

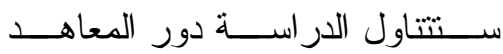

التعليمية الخاصة بمحافظة الدقهلية في تلبيـــة متطلبات سوق العمل من خلال عدة محـــاور ، حيث يتتاول المحور الأول الفلسفة الحاكمة للمعاهد التعليمية الخاصة ، ويعرض المحور

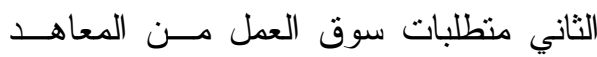
النعليمية الخاصة ، ويرصد المحور الثالــث دور المعاهد التعليميــة الخاصـــة بمحافظـــة

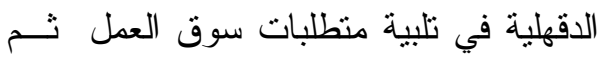
وضـع مجموعة من المقترحات لتفعيـلـل دور

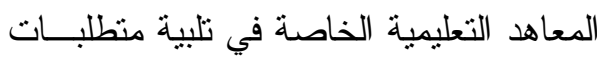

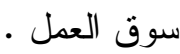

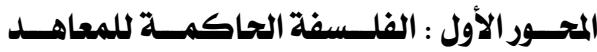
التعليمية الخاصة : الإل

(1) مفهوم المعاهد التعليمية الخاصة: -

تختلف تسميات المؤسسات التعليميــة

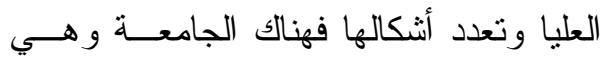
أعلى مؤسسة معروفة فــي التعلـــيم العــالي وهناك أسماء أخرى نطلق علــى الجامعـــة
الاليل الوثائقي الخاص بالــشر اكات الفعالـــة و المقابلات الشخصية مع الافر اد المشاركين في الثر اكة في جميع المستويات.

وقد توصلت الدراسة إلى مجموعــة مــن النتائج منها : - أهمية عامل الثقة في الثر اكات الفعالـــة بين أطر اف الــشر اكة لزيــادة فاعليــــة الثر اكات و استمر اريتها. ــ أهميــة الخبـــرة التعليميــة و التدريبيــــة للأعضاء المشاركين في الثر اكة وفــي ولني

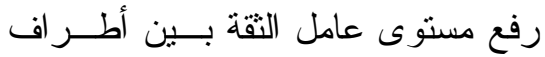

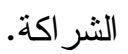

r- دراسة ريتشارد (2005) Richards) هدفت هذه الدر اسة إلى تحقيق الفعالية

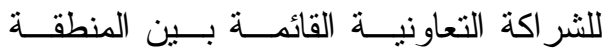

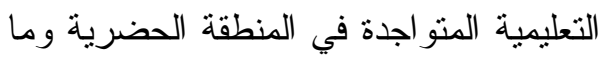
يتبعها من ادار ات و المدارس و المعاهد مــن جهة و الكلية المتخصصة بإعداد المعلمين في وناس المنطقة الحضرية نفسها في ولاية كاليفورنيا من جهة أخرى بغرض دعم التتمية المستمرة للمعلمين الممارسين للمهنة. وقد توصلت الدر اسة الــى الــشر اكة

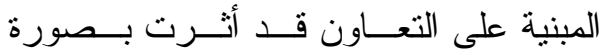
جو هرية على الادارة التعليميــة و المـــارس لتدريسية والكليات المشاركة في المنطقة وقد قررت المنطقة الحضرية توسيع نطاق هـــه الثر اكة في الأعو ام المستقبلية. 
فالأكاديمية: هي مدرســة فلــسفية أسـسـها

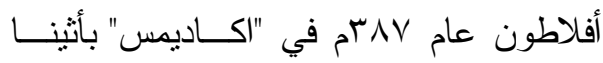

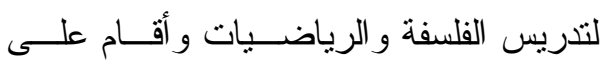

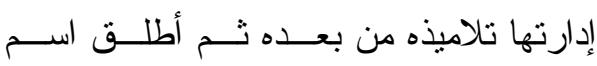

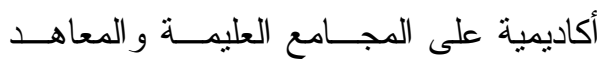
الأدبية منل الأكاديمية الفرنسية التي أسـسها

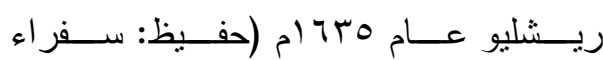

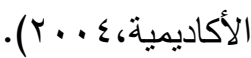

وتتعرفها الدر اسة بأنهـــا "مؤســسات

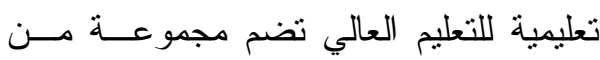

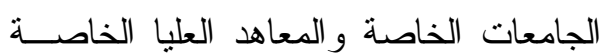
و الحاصلة على مو افقة وز ارة التعليم العسالي ولي لماهي

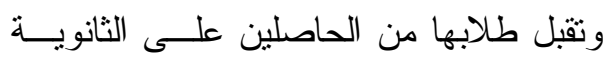

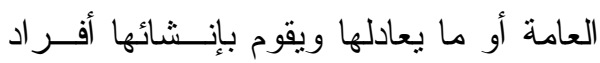
المجتمع المصري والذين يقومون باســتمار

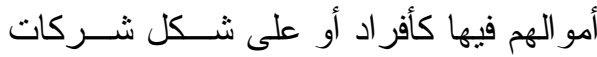
أهلية اســتثمارية مـسـاهمة وتتــولى وزارة التعليم العالي الإثر اف عليها." ب- المعاهد العليا الخاصة:

يعتبر معهداً عالياً خاصاً "كل منـشـأة

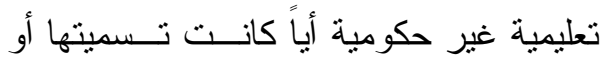
جنسيتها يلتحق بها الطلبة من الحاصلين على لئل

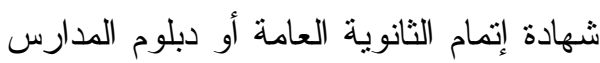
الثانوية الفنية أو ما يعادلها وتقوم أصـــلاً أو

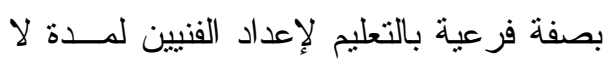

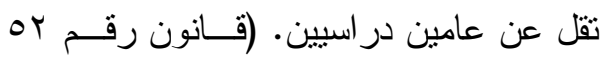

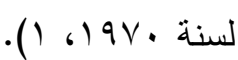

و المؤسسات التابعة لهـــا مثـــل الكليــات و و

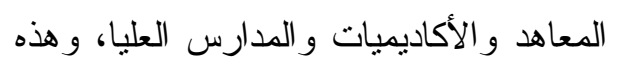

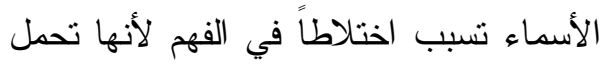
معاني مختلفة من بلد لأخرى، فعلى الـــرغم

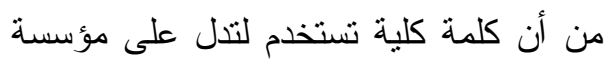

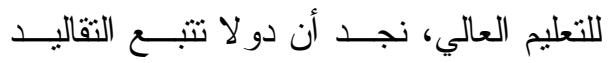

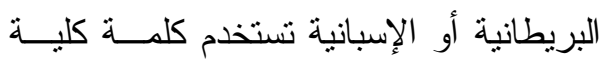

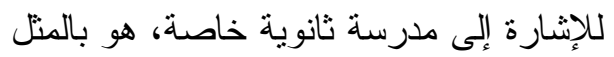
فإن الأكاديمية ربما تدل على مؤسسة للتعليم العــالي أو مدرســـة (الموســـوعة العربيـــة

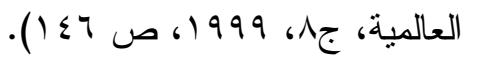
وفيما يلي عرضاً لتلك المفاهيم ذات الــصلة

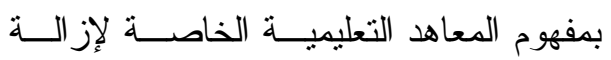
اللبس بها :1 - مفهوم التعليم العالي:-

"يقصد بالتعليم العالي التعليم الذي يتم

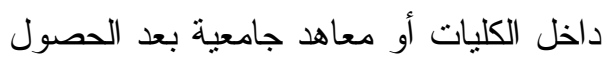

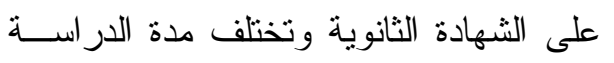

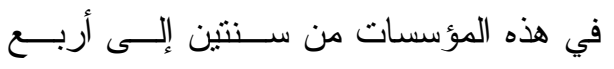
سنوات وهي أخر مرحلة من مراحل التعليم

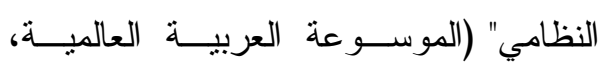

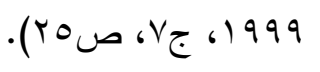

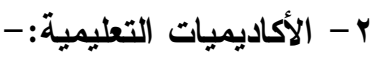

كلمــة أكاديميــة Academy كلمـــة

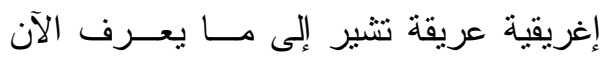

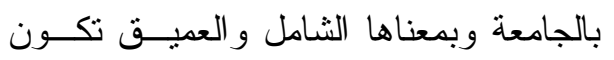

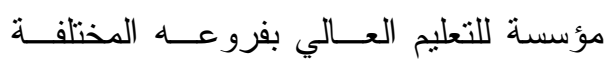


القطاعات المختلفـــة ومنهـــــــــالات مجـات الإلكترونات و النتييد و البناء و غير ها من المجالات التي تخدم المجتمع. - المساهمة في تكوين كوادر من هيئسات

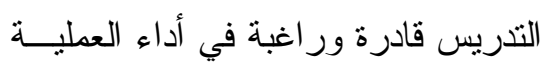

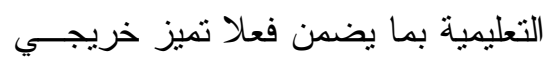

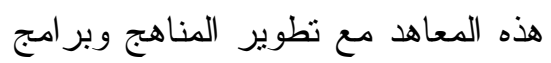

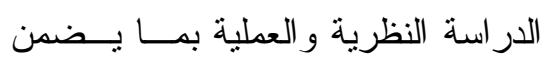
التلاؤم مع التطور التكنولوجي.

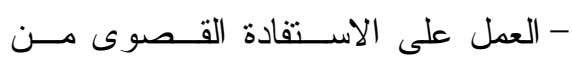
إمكانيات قطاعات الإنتاج و الخدمات في تدريب طلبة هذه المعاهد إلى المـستوى ولئن

$$
\text { المستهدف. }
$$

- توثيق التعاون مع الاتحادات التجاريــــة

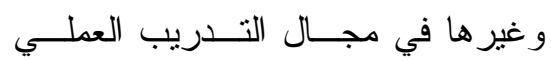

$$
\text { و المهني. }
$$

- القيام بالدر اسات الميدانية اللازمة لخدمة

$$
\text { البيئة و المجتمع في المجالات المختلفة. }
$$

وترى الدراسة أن القائمين على إدارة

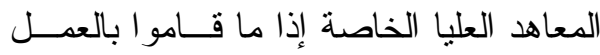

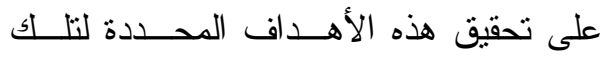

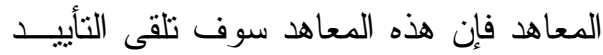

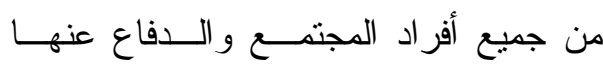
ومساعدة التعليم العالي الحكومي فــي حـلـ

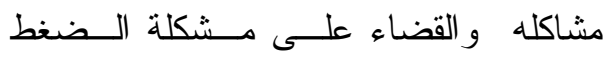
المتز ايد على الجامعات المصرية وتحـسين ودين جودة الخريجين و القضاء على مشكلة البطالة
(Y) أهداف المعاهد التعليمية الخاصة:

إن الأهداف هي نقطـــة البدايـــة لأي

عمل سواء كان هذا العمل في إطار النظــام التربوي أو أي نظام آخر فهي تعــــ القائـــ

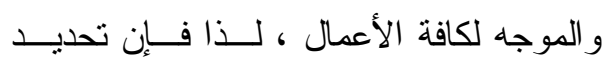
الأهداف ضروريا لأي مؤسسة تعليمية ير اد منها توجيه الجيل وبناء صر ح الأمة وتعيين أسلوب السلوك في حياة الفرد و الجماعـــة ،

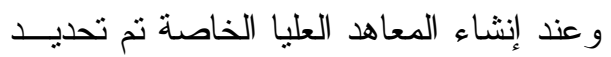
الأهداف المنشودة من وجودها وهي :

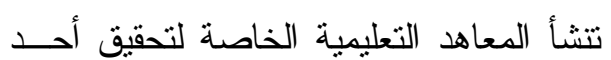

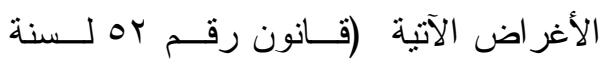
$-:$ () ( $97 \mathrm{~V} \cdot$ ،

• المعاونة في تحقيق الأهداف التعليميـــة

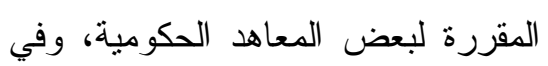

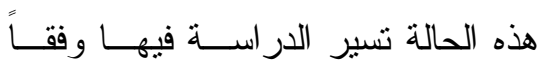
لخطط ومناهج الدراسة المقرة بالمعاهد

$$
\text { الحكومية المماثلة. }
$$

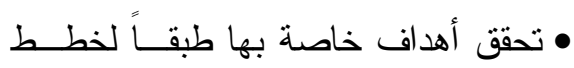

ومناهج دراسية تقرر ها وزارة التعلـيمي

$$
\text { العالي قبل تتفيذها. }
$$

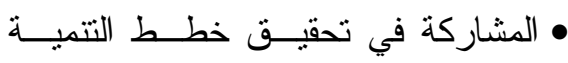

$$
\text { ووضع العلم في خدمتها. }
$$

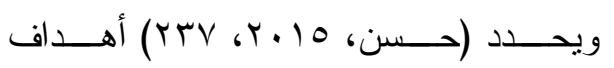
المعاهد العليا الخاصة في النقاط الآتية: - الإسهام في تكوين طبقة من الاخصائيين

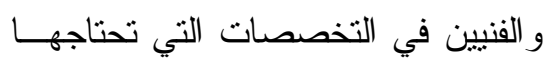


- أن يكون متفرغا للار اسة بالمعهر وذلك

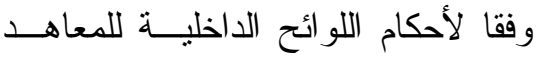

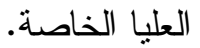

- أن يكون محمود السيرة حسن الـسمعة.

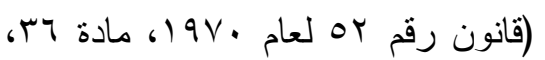

وتوصــلت الدر اســـة مسـن خــلال

المقابلات مع بعض أعضاء هيئة التـدريس

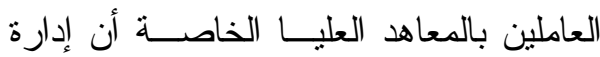

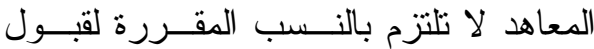
الطلاب و التي تنتاسب مع عدد أعضاء هيئة

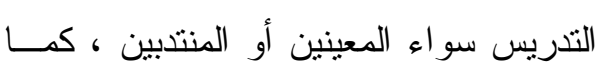
أن المقابلات التي تتم للطلاب في بداية العام

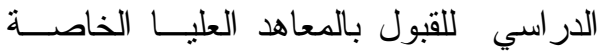
تكون بصورة شكلية ويرجع ذلك إلى ارتفاع عدد الطلاب المتقدمين للار اسة بتلك المعاهد، كما أن المجاملات في القبول تكون و اضحة لأبناء القائمين على ادارة تلك المعاهد وهــو لكون ما يتتاقض مع مادة (ع) من قانون رقم لr مانه لعام • 19V و الذي يحــد سياســية القبــول بالمعاهد العليا الخاصة .

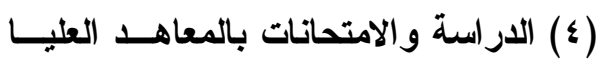
الخاصة ونظام التقويم بها والات بالهان

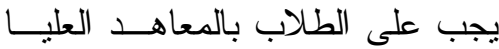
الخاصة الحضور بانتظام ومتابعة الــدروس

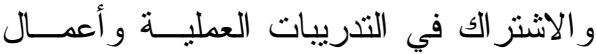
الورش و القاعات البحثية وفقا لأحكام اللائحة
من خلال تخريج أجيال قادرة على العمل مع

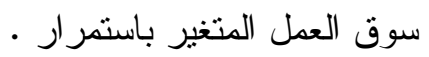
(r) سياسية القبول بالمعاهد العليا الخاصة:

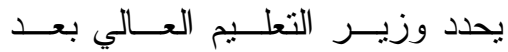

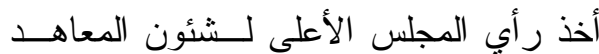
في نهاية كل عام جامعي عدد الطلاب مــن

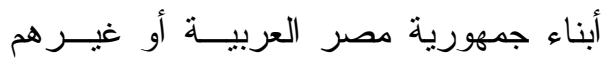

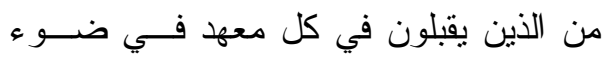

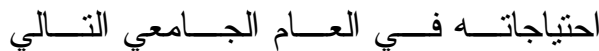

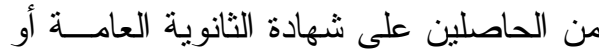

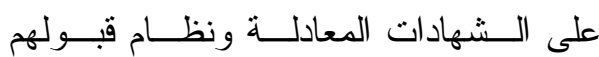

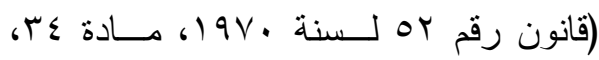

يكون نرشيح الطلاب للمعاهد العليــا عن طريق مكتب تتسيق القبول ما لم يصدر قر ار من وزير التعليم بغير ذلك ويشترط في قيد الطالب ما يلي: - أن يكون الطالب حاصلا علــى شــــادة

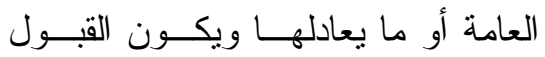

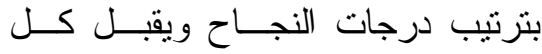
الحاصلين على دبلوم مدارس الثانويــة الفنية في بعض المعاهد.

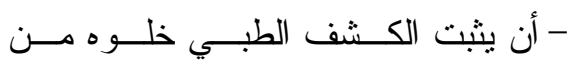
الأمر اض المعدية وصـــلاحيته لمتابعـــة الدر اسة وفقا للقواعـــ التــي يحــددها المجلس الأعلى لثئون المعاهد. 
و الرسوب مرنبة حسب الحسـروف الهجائيـــة

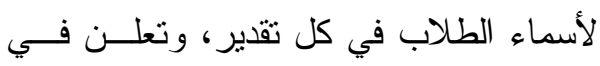

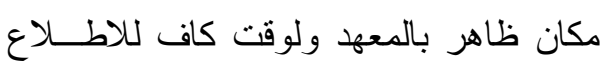

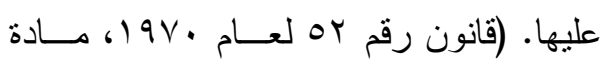

ويقوم المعهد بتحرير شهادات مؤقتة

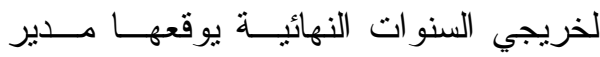

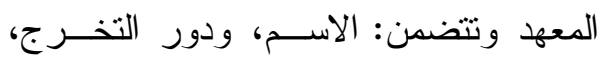

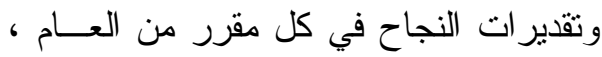

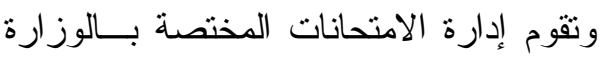

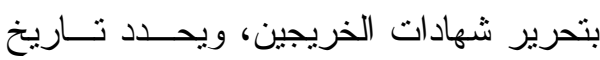
منح الدرجة أو الثهادة من تــاريخ اعتمــاد وزير التعليم لنتيجة الامتحانات.

وتزى الدر اسة أنه اذا ما تم متابعسـة

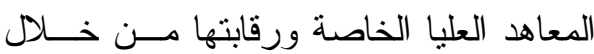
or الجهات و الهيئات التي حددها قانون رقها لعام • 19V ، و و إذا ما تم تفعيل زيار ات لجان التقييم التعليمية لكل عام وتقديم تقرير التقييم

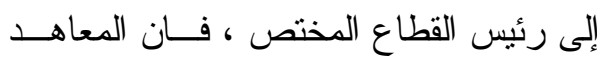

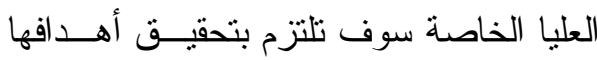

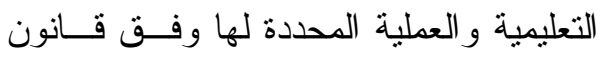

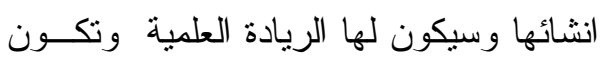
قادرة على منافـسة المؤسـسـات الجامعيــة

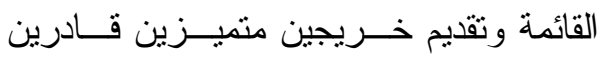

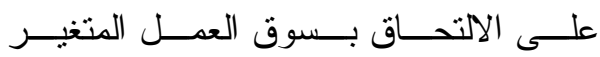

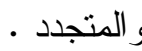

، ولمجلس المعهد أن يحرم الطالب من التقدم للامتحانات كلها أو في بعض المو اد إذا رأى لئ لهن

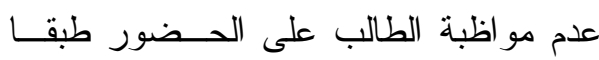

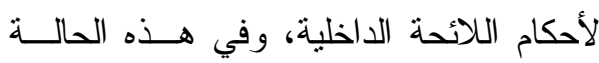
يعتبر الطالب راسبا في المقررات التي حرم من التقدم للامتحان فيها. ويجوز لمجلس إدارة المعهد أن نوقف قيد الطالب لمدة سنة در اسية ، ولا تزيد عن سنتين إذا تقدم بعـــر مقبـول يمنعــه مــن الانتظام بالدراسة ويجــوز لـــئيس الإدارة

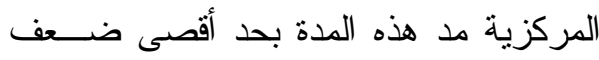

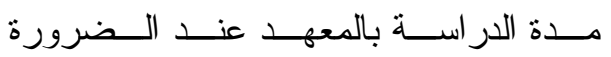
القصوى.(قانون رقم roلسنة • 19V، مـادة $\left(\leqslant r_{6}, r\right.$. ولا يكون النقل من سنة إلى أخــــى إلا في نهاية السنة الدر اسية، و لا يعاد امتحان

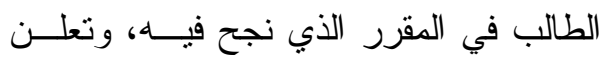

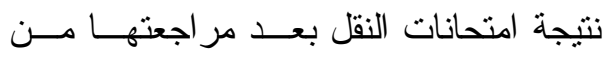

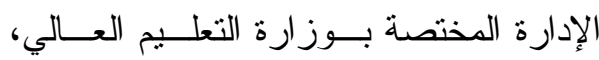
و اعتمادها مــن رئسيس الإدارة المركزيــة

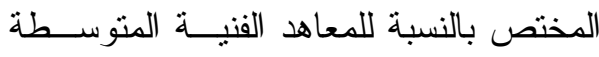
الثابعة للوزارة، ومن مجالس إدارات المعاهد

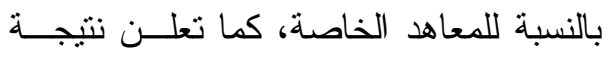

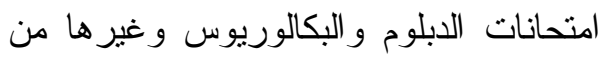
الثهادات بعد اعتمادها من وزيــر التعلــيم بكثوف منفصلة لكل من الناجحين بتقدير اتهم

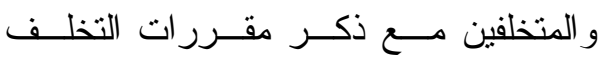




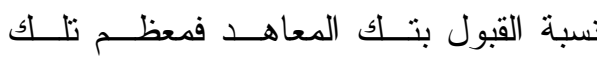

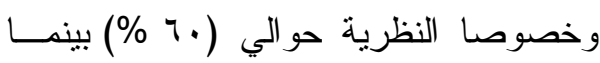
يكون القبول في المعاهد ذات التخصــصات

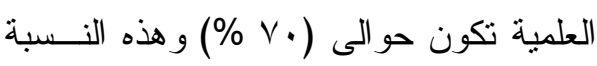

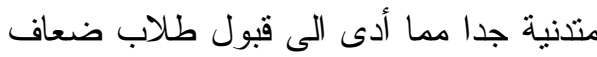

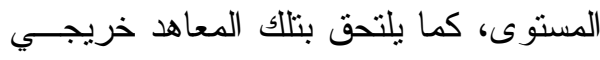
التعليم الثانوي افني و التجاري مما أدى الــى لـى بلى خلئ حدوث خلل في مخرجات تلاك المعاهد و وعدم ملائمتهم لاحتياجات سوق العمل. - العزلة و الفصل بين التعليم والعمل : فالمعاهد التعليمية الخاصة كل عـام

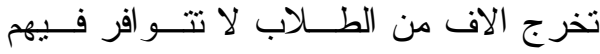
مهار ات واحتياجات سوق العمل و السبب في ذللك يرجع الى الفصل بين ما يتعلمه الطلاب

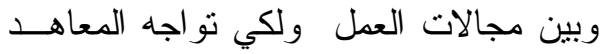

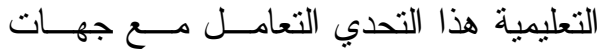
التوظيف وسوق العمل و القطـــاع الخــاص و المؤسسات الحكومية لتقليل الفجــوة بــين كفاءات الخرجين وما يتطلبه سوق العهــل . وتقترح الدر اسة لمعالجة هذا التحدي ثقـديم

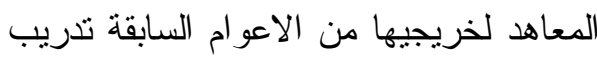

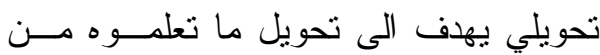

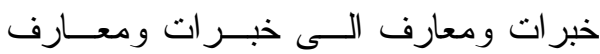
يطلبها ســـوق العــلـ ويلتحــق بالتــدريب

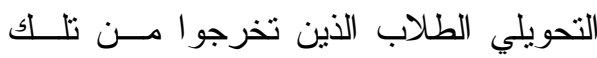
المعاهد و لا يستطيعون اللحاق بسوق العمـلـ
(0) التحديات التي تواجه المعاهد التعليمية الخاصة :

تو اجه مؤسسات التعليم العالي بصفة عامة و المعاهد التعليمية الخاصة مجموعــة من التحديات منها انتاج المعرفة وتحـديات

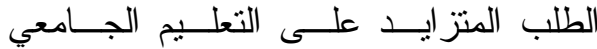

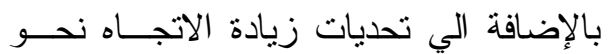
الخصخصة ، وتتتاول الدر اســـة التحــديات التي تتعلق بالمعاهد التعليمية الخاصــة فــي

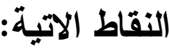

\section{- زيادة كلفة التعليم بها :}

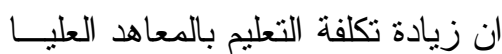

الخاصة من عام الى عام تتـــن تحـديان رئيسيان للمعاهد العليا بصفة عامة و الجهات المشرفة على تتمية المو ارد البشرية أحدهما

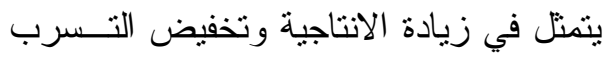

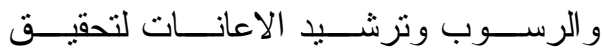
موفورات فـي المــصروفات و الاســتنمار والاخر يتمثل في تحسين نوعيــة البــر امج

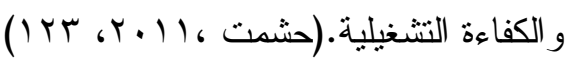
- سياسة القبول :

حيث أدت زيــادة عـدد الخــرجين بالمرحلة الثانوية ورغبــة جميـع الطــلاب اللحاق بالتعليم العالي ونتيجـــة لعـدم قــدرة الجامعات الحكومية من قبول جميع الطلاب لجأ الكثير من الطلاب الى المعاهد التعليمية

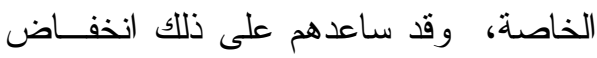


ولمو اجهة التحــديات التــي نواجـــ

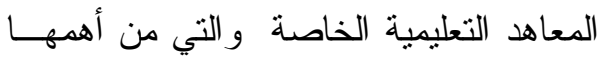

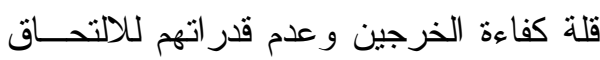
بسوق العمل ، ومن ثم فقد طالــبـ الكثيــر ضرورة حدوث شر اكة بين المعاهد التعليمية الخاصة وسوق العمل.

\section{(7) المعاهد التعليمية الخاصة بالدقهلية:}

تتتوع المعاهد التعليمية الخاصة فــي محافظة الدقهلية، وتبلغ عدد المعاهد التعليمية

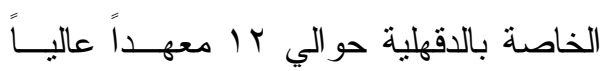

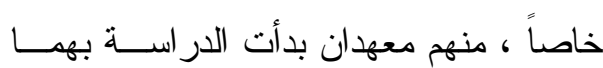

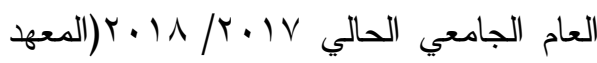

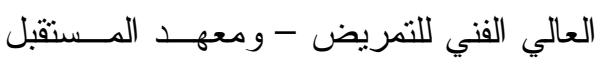
العالي للهندسة و التكنولوجيا) وييلــغ عـــد المعاهد العليا تخصص الهندسة أربعة معاهد وليد تمنح درجة البكالوريوس في الهندسة ومــدة

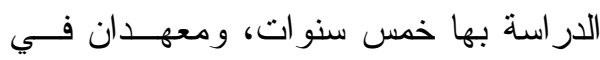

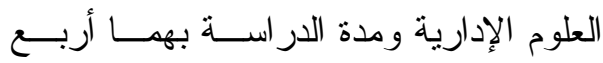

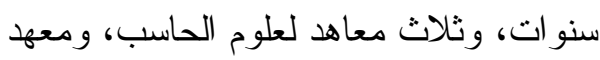

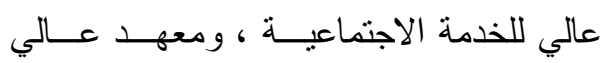
للغات، ومعرة عالي فني تمريض.
لعدم تو افر المهارات اللازمة للحاق بـسوق

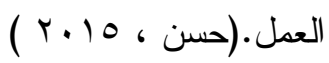

بالإضافة الى ضرورة تفعيل الانشطة العلمية و الثقافية و الرياضــية و الاجتماعيــة و الفنية لتدريب الطلاب على مهار ات العهـلـل الجامعي و العمل في فريق و القدرة على اتخاذ القرارات وغير ذلك مــن المهــار ات التــي وني يطلبها سوق العمل، كما يساعد ايجاد نو اصل مستمر مع رجال العمال ومنظمــات قطـــاع

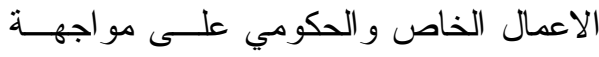
تحدي الفصل بين العلم و العمل. - أزمة القيادة في المعاهد التعليمية :

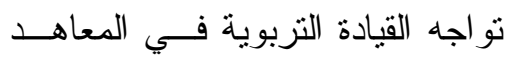

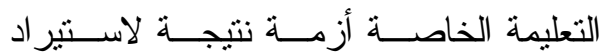

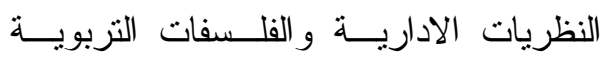
الغربية وتدريس الفكر الاداري الغربي فـي ولي مناهجها بالرغم من اختلاف المجتمعات التي

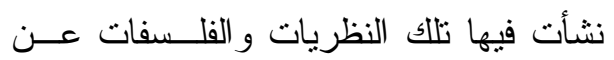

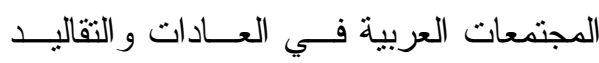

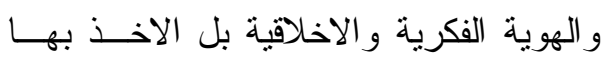
كمبادئ في القيــادة التزبويـــة فـــي التعلــيم وتدريسها لمديري المعاهد. 
وفيما يلي عرض تفصيلي للمعاهد العليا الخاصة في محافظة الدقهلية.

جدول (1) المعاهد العليا الخاصة في محافظة الدقهلية

\begin{tabular}{|c|c|c|c|c|}
\hline رقم القرار وتاريخ & الإجة & عدد سنوات & اسم المعهذ & b \\
\hline & البكالوريوس & ع سنوات & المعهد العالي للخدمة الاجنماعية & 1 \\
\hline 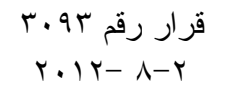 & البكالوريوس & 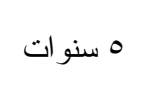 & معهد النيل العالي للهندسة و التكنولوجيا & r \\
\hline 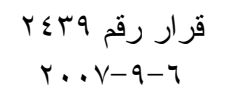 & البكالوريوس & م سنو ات & معهد الدلتا العالي للهندسة و التكنولوجيا & r \\
\hline 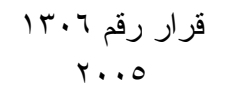 & البكالوريوس & مسنو ات & معهد مصر العالي للهندسة و التكنولوجيا & $\varepsilon$ \\
\hline 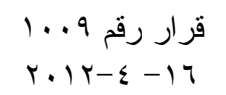 & البكالوريوس & ع سنو ات & المعهد العالي للعلوم الإدارية بالمنزلة & 0 \\
\hline 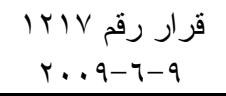 & البكالوريوس & ع ع اتو ات & المعهد العالي للعلوم الإدارية ببلقاس & 7 \\
\hline ق قرار رقم عابا & البكالوريوس & 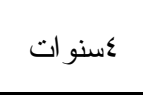 & $\begin{array}{c}\text { معهد مصر العالي للتجارة و الحاسبات } \\
\text { بالمنصورة }\end{array}$ & 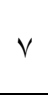 \\
\hline 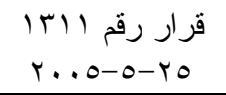 & البكالوريوس & عنو ات & معهذ النيل العالي للعلوم التجارية وتكنولوجيا & $\wedge$ \\
\hline 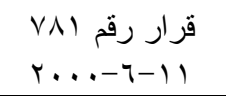 & البكالوريوس & عسنو ات & معهد الدلتا العالي للحاسبات & 9 \\
\hline 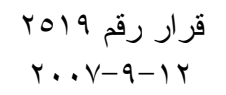 & البكالوريوس & ع عنو ات & المعهد العالي للغات بالمنصورة & 1. \\
\hline 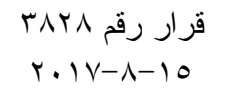 & البكالوريوس & ه سنو ات & معهد المستقبل العالي للهندسة و التكنولوجيا & 11 \\
\hline$r \cdot i r$ & البكالوريوس & عسنو ات & المعهد الفني للتمريض بالمنصورة & ir \\
\hline
\end{tabular}

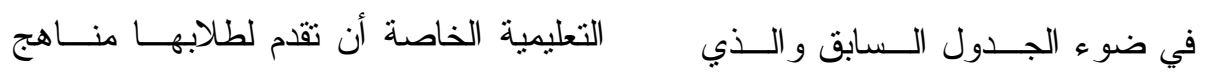

يوضح عدد المعاهد التعليمية الخاصــة فـي ت تعليمية تتو افق مع متطلبات سوق العمل .

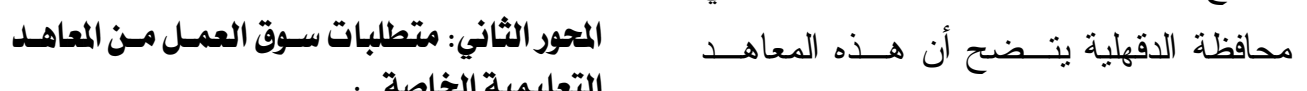
التعليمية الخاصة :

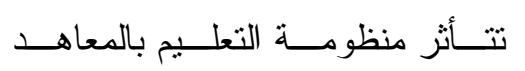

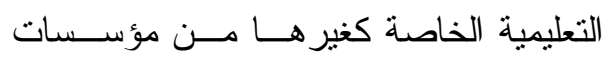
المجتمع بآليات السوق المحلي و العالمي، لذا فان كفاءة مؤسسات التعليم بتلك المعاهد اليوم أعدادها في نز ايد مستمر ويتخرج منها عدد كبير من الطلاب كل عام ، و التي لا تتو افق مهار اتهم مع متطلبات سوق العمل المتغيــرة

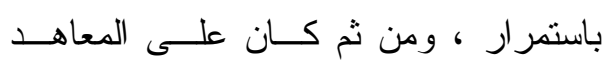


r- وضع السياسات اللازمة لتحقيـق هـــه

$$
\text { الأهداف ومن أهمها:- }
$$

- السياسة التمويلية: المتمنلـــة بـضـرورة

تخصبص مبالغ مناسـبة (نسبة مسـن

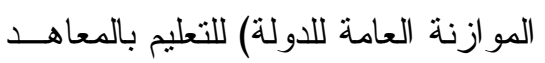

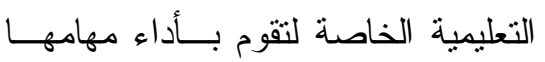

بالشكل الصحيح.

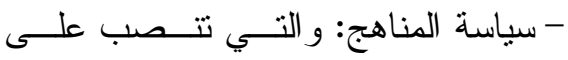

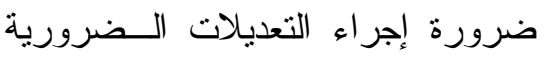

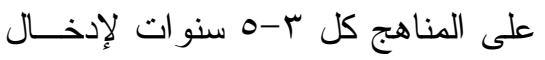

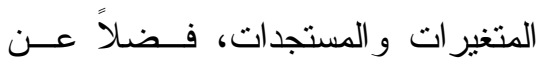

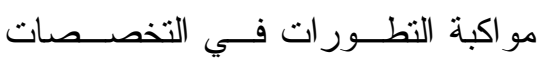

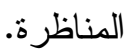

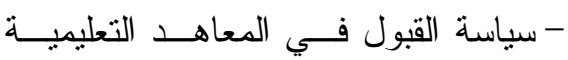

الخاصة : ضرورة وضع أسس للقبــول

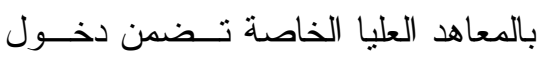

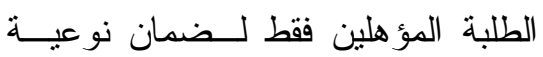

الخريج.

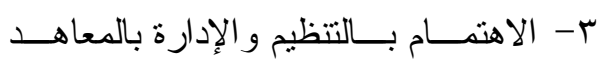

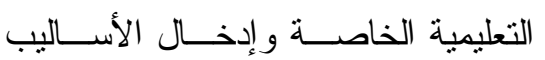

$$
\text { الحديثة فيها. }
$$

ع - الاهتمام بالدر اسات العليــا مــن حيــــ

النوع ووضع محددات للقبول تـضمن

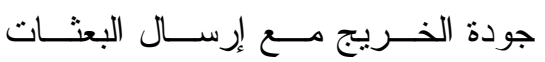

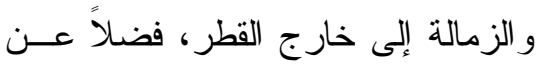

توفير منطلبات البحث العلمي للطالــب

$$
\text { و الأستاذ. }
$$

أصبحت تقاس من خلال مدى ثقارب وتلائم

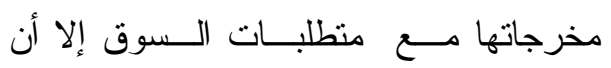
أوضاع السوق تتسم بالتقلب و التغير المستمر

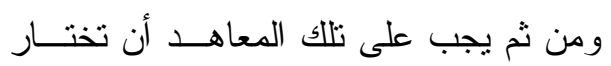
أمراً من أمرين:

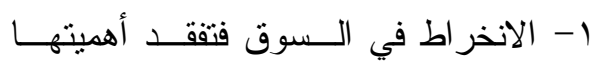

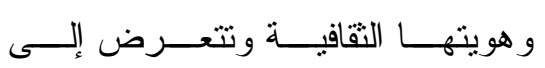
اهتز از ات شديدة بسبب تقلباته.

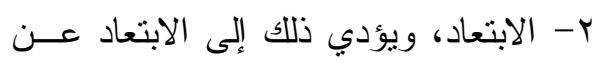

$$
\text { روح العصر • }
$$

ذللك لأنه بسبب التكتلات الاقتصادية

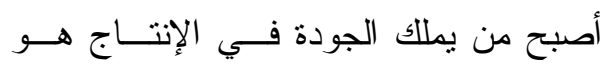
المتحكم في السوق وبذلك يتضح دور التعليم

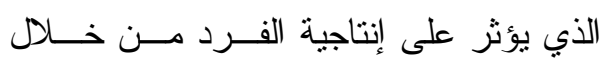

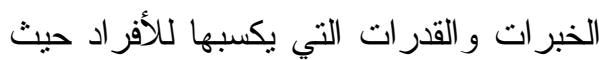

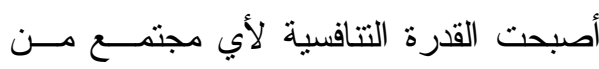
المجتمعات تتوقف على مدى امتلاكى أفــــر اده

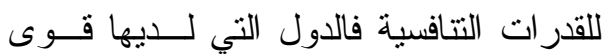

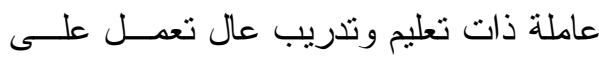

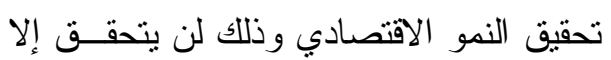

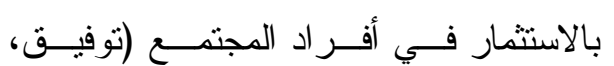
. ( r r...V

ويعدد الباحثين متطلبات واحتياجات

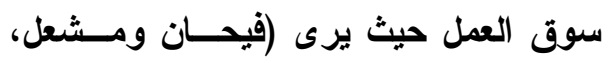

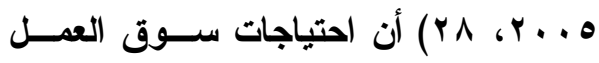

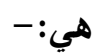

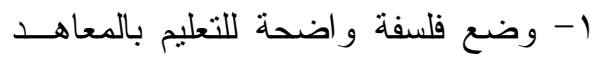
التعليمية الخاصة وتحديد أهداف محددة. 
ويشكل الربط بين التعلـيم وسـوق

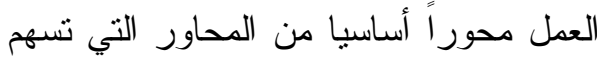

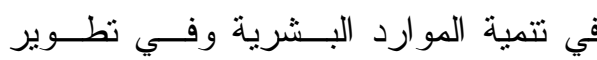

اقتصاد أي دولة ، فبقدر ما يكون الربط بين

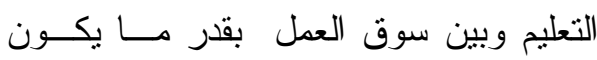

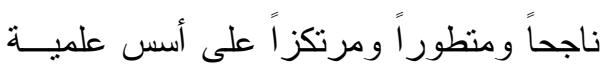

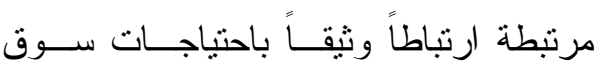

العمل، يكون محورًا فاعلاً في نمو الاقتصاد الوطني القومي و ازدهار ها.

ويهذف الربط بين التعـــيم وســق العـــل

$$
\text { بالمهن المختلفة ما يلي:- }
$$

- ربط التعليم وسوق العمل بخطط التتمية

الاقتصادية.

- إعداد الأيدي الماهرة في شتى المجالات

وتأهيلها للإسهام في خطط التتمية.

- العمل على تأهيل الطلاب و المتــدربين

$$
\text { وفق قدر اتهم وميولهم. }
$$

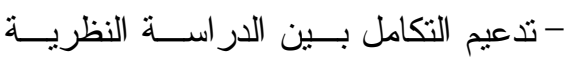

و الدراسة العملية النطبيقيــة و إكــساب

الطــلاب المتــدربين طريقـــة التفكيـــر

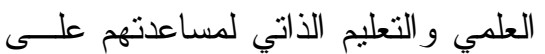

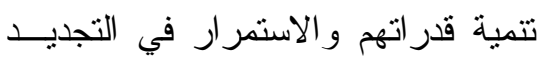

و الابتكار و الوصـــول إلــى مـستويات

مهنية تفي بحاجات العمل فـي ميــادين

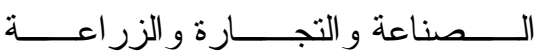

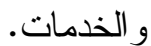

0- ضرورة إصلاح المؤسسات التعليمية في

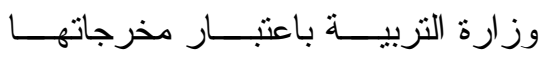

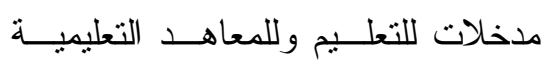

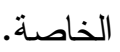

ج- الموازنـــة بــين الجو انــب النظريــــة

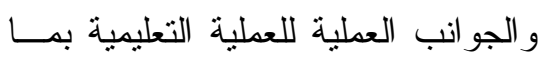

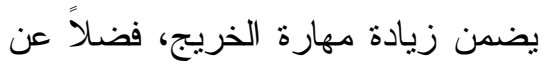

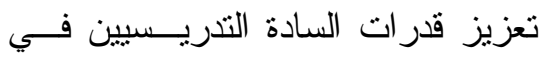
المجال العملي.

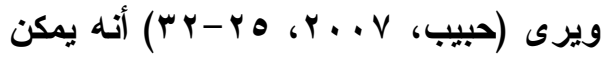
تحديد متطلبات سوق العمل في:1 - الربط بين التعليم العالي وسوق العمل.

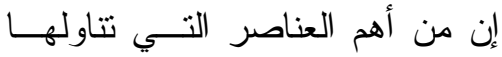

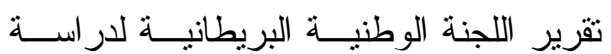

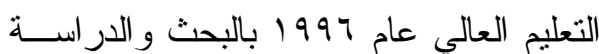
حتى توفر الحكومة الإمكانيات في العـشرين

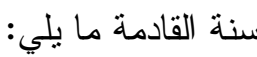
- التخطيط المرن الـــي يتجــاوب مـــع

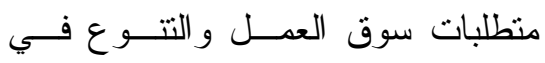

$$
\text { البرنامج و التأهيل. }
$$

- مضاعفة مصادر تمويل التعليم العالي.

- استغلال المصادر و الامكانيــات مثـــل

المكتبات وبنوك المعلومات و المعــدات

البحثية المتخصصة.

$$
\text { - المعايير و الجودة. }
$$

- مناهج التعليم بالمعاهد التعليمية الخاصة. 
و الاتصالات في تيــسير العمليــة التعليميـــة

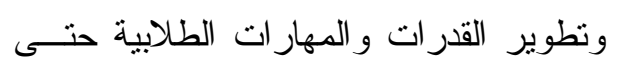
يكون الطلاب مهيئين ليس لمجتمع اليـوم- ولئي

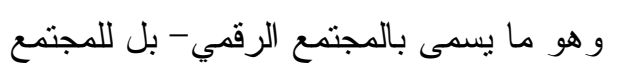
المستقبلي القادم.

إن التغيرات التي حدثت اليوم بسبب الفي

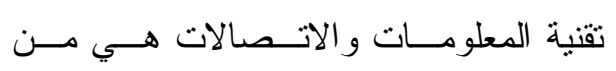

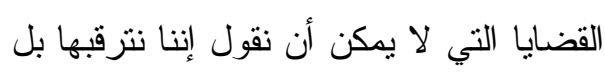

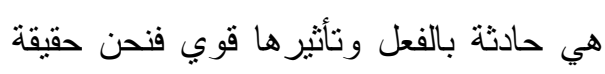

$$
\text { وسط هذه التغير ات. }
$$

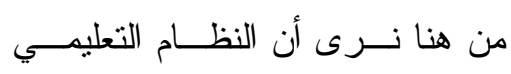

بشكل عام على مفترق طرق بـشأن ثــاتلاث

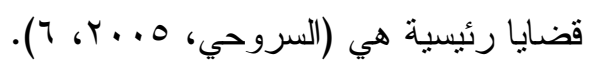

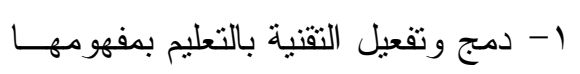

$$
\begin{aligned}
& \text { الو اسع. } \\
& \text { r- مو اجهة الثورة المعرفية. } \\
& \text { r- ناتج تعليمي عالمي. }
\end{aligned}
$$

بناءً على ذلك فإن الساسة التربـــيـين

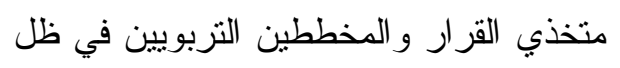
هذه التغيرات التاريخية لاثك أن لهم أدواراً

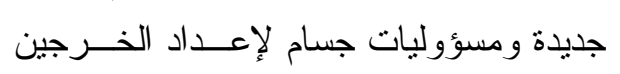

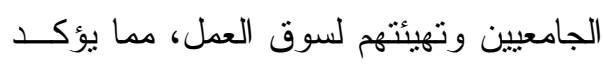

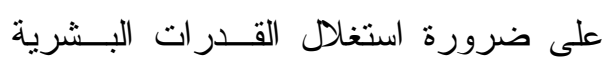

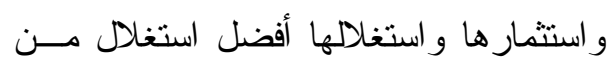

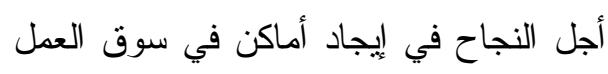

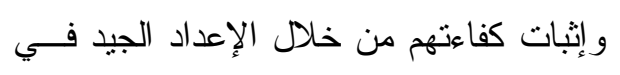
التعليم الجامعي.
- توجيه مناهج وبر امج التعليم و التـدريب

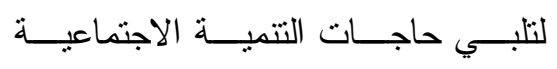

$$
\text { و الاقتصادية. }
$$

- إكساب الطلاب المتــدربين المهــارات

و الخبرات النظرية و العملية بما يسسهل

$$
\text { أداء العمليات المهنية. }
$$

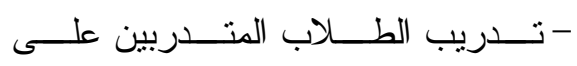

اقتصاديات العمل بما بحقق الإنتاج بأقل كلفة ممكنة وبأقل وقت.

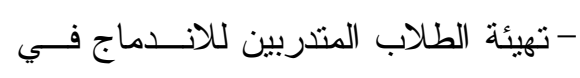
سوق العمل و الإسهام فيه.

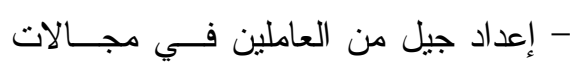

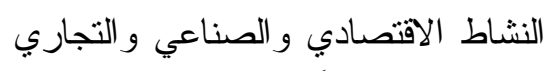

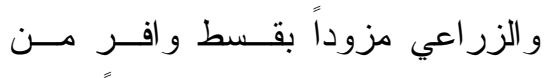

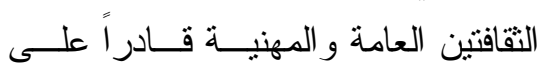

$$
\text { أحدث الأساليب و الأجهزة. }
$$

r - ضـــرورة إصــلاح التعـــيم الجــامعي لمواجهة متطلبات سوق العمل:

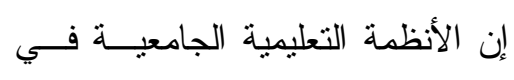

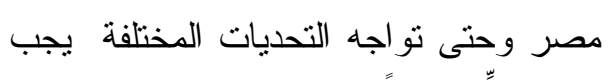

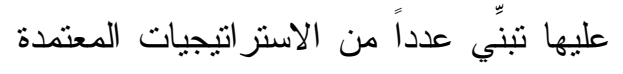
على التخطيط الاستر اتيجي منتوسط وطويـلـل

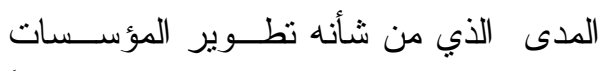

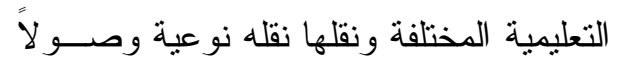

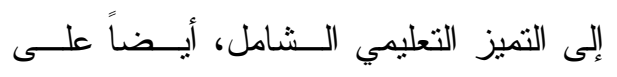

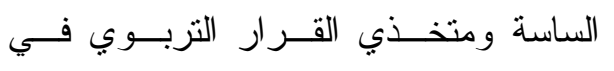

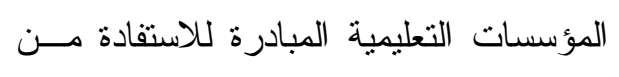

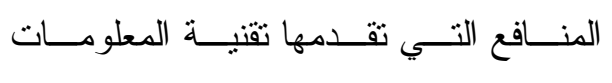




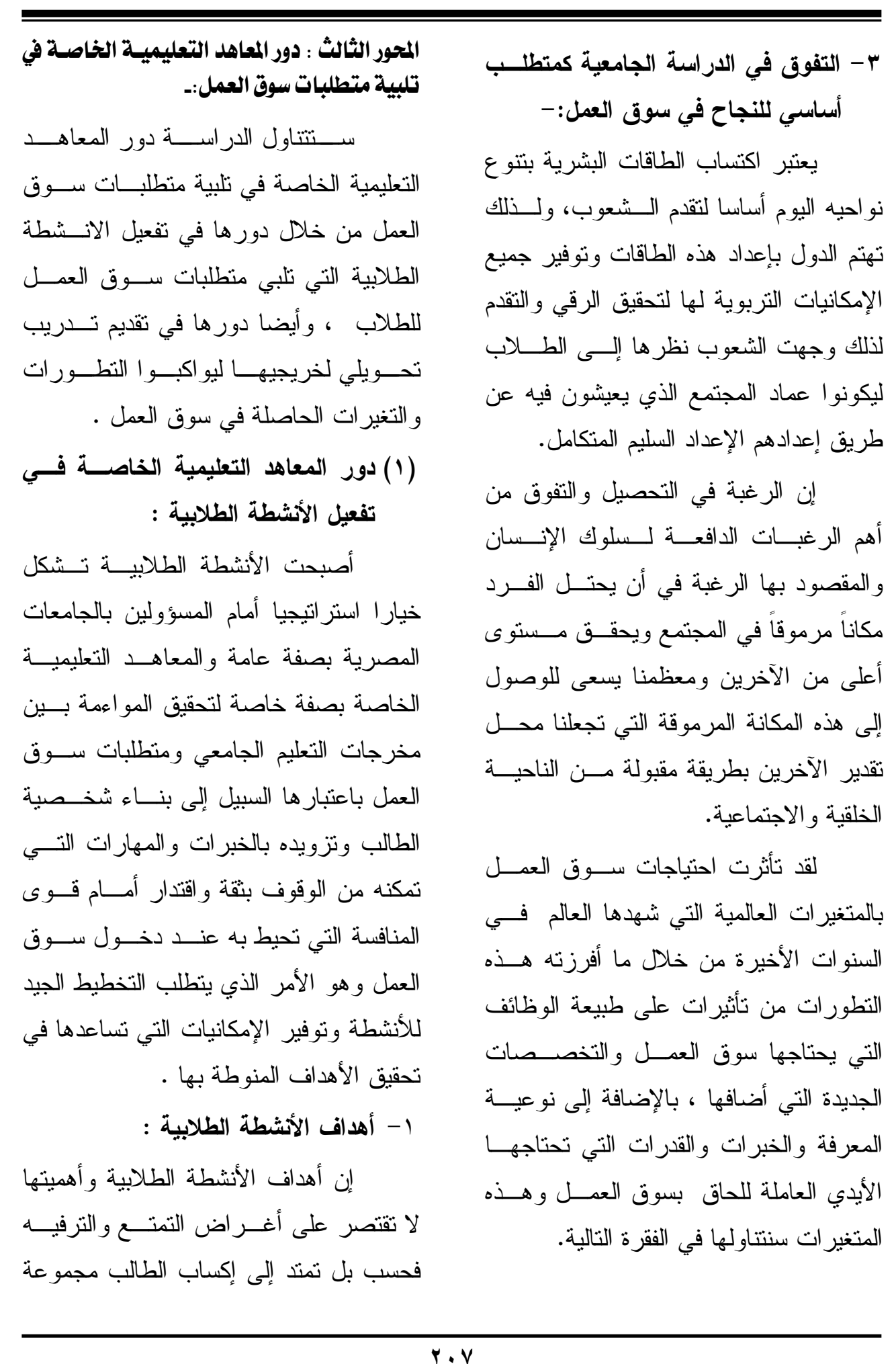


وتتمية قدرته على التخطــبط و التتظــيم

و التنفيذ في مختلف جو انب حياته .

كما أن مشاركة الطلاب في الأنشطة

تساعدهم في التغلب على الكثير من الآتــار

و السلوكيات السلبية كالعنف و ارتفاع معدلات

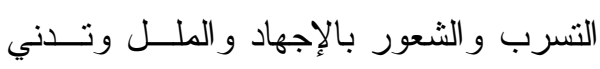

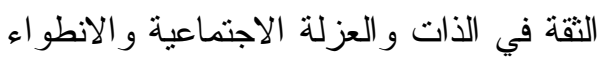

و غير ها بالإضافة إلى تحسين مستوى الأداء

الأكاديمي و إمكانية النتبؤ بتحصيله الدر اســي لإصي

في السنو ات التالية وذلك مقارنةً بأقر انه الذين الذين

$$
\text { لم يشاركو ا في الأنشطة . }
$$

r - خصائص الأنشطة الطلابية :

يرى ( اســماعيل وعبــــ الحــافظ،

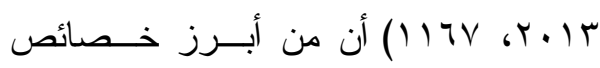

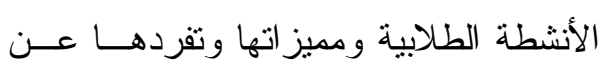

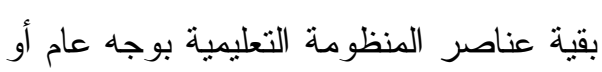

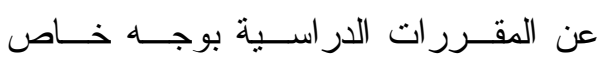
ما يلي :

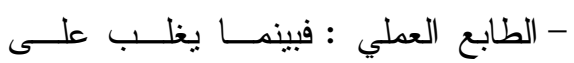

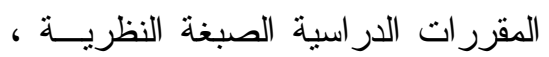

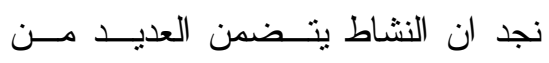

الممارسات العملية كممارسة الرياضـــة

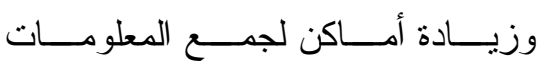

و المعسكر ات الطلابية وغير ها ، كلهــا

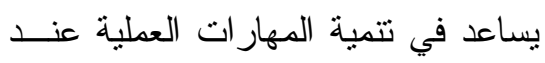

الطالب.
متتو عه من القدرات و المهار ات التي تساعده على ربط العلاقة الأكاديمية بالخبرة العمليــة

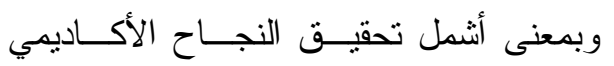

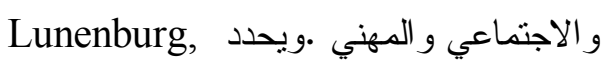
(2010,1-3) أهداف الأنـشطة الطلابيــــة وأهميتها في أربع نقاط أساسية :تعزيز التعلم

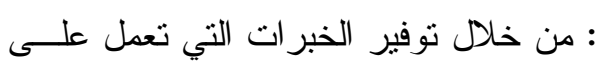
توسيع و إثراء العمل داخل القاعات الدراسية ومن ذللك نشاط النوادي العلمية .

- استكمال منطلبات المقررات الدراسية : و هذا هدف يرتبط بالهدف السابق حيــث

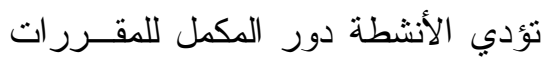

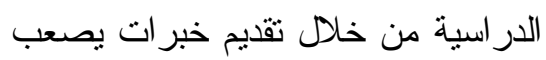
تضمينها في هذه المقررات .

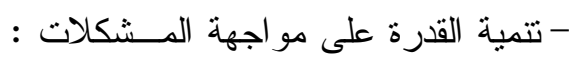
حيث تربط الأنشطة العديد من جوانـبـ مولبه

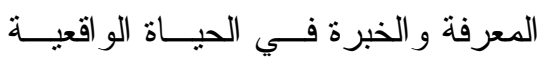

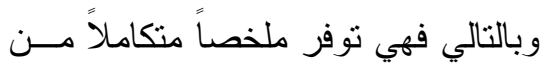
مو اقف حياتية وفروع معرفية معينة تفيد الطالب في التعامل الفعال مع المشكلات

$$
\text { التي تو اجهه . }
$$

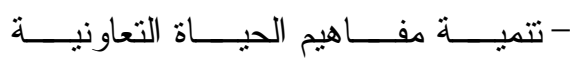
و الديمقر اطية : فالأنشطة تتيح للطالــبـ تجربة المشاركة في الإدارة من خــلال

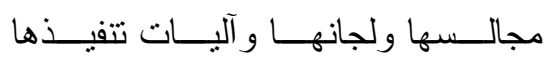
المنتوعة بما يساعده في نكوين علاقات

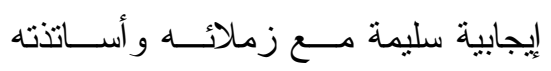


- مهارات التعامل مع تكنولوجيا الاتــصال

و المعلومات :

إن اعتماد أسواق العمل العالمية ومن

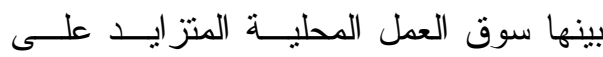

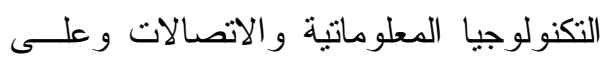
الذكاء الاصطناعي وعدم الثبات والأمان في ولاتيات الوظائف التقليديــة و اســتحداث متطلبـــات وحاجات جديدة على مو اصــفات ومهــار ات وكفاءات وخبرات الموارد البـشرية التـي سيعتمد عليها سوق العمل في تسيير شؤونه الأساسية ومن ثم يتطلب سوق العمل اليــوم

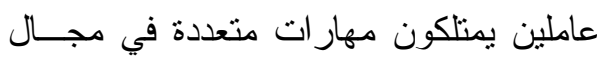

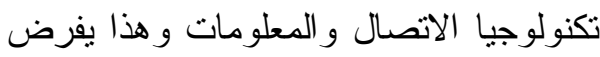

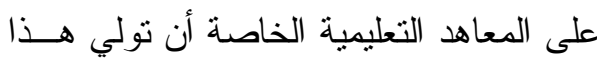

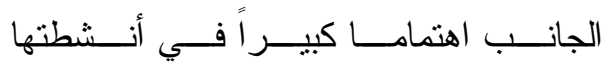
المختلفة . - مهارات الإبداع والابتكار :

يمنل النشاط الإبداعي حاله من التغير في السلوك نتيجة التغير في اتجاهات الطلاب

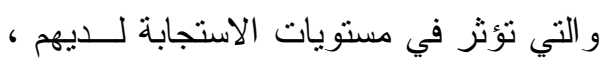

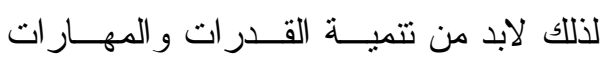
الإبداعية للطلاب لنساعدهم على أداء عملهم بطريقة إبداعية كالطلاقة في التعبيـر عـنـ التصن تصور اتهم الفرية و إبداء الرأي و المرونة في في لئية التقليد و ايجاد الحلول و البدائل المناسبة لما قد ولد

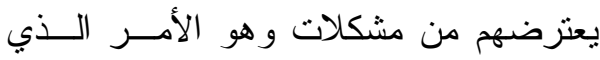
يفرض على المعاهد التعليمية بصفة عامـــة
- كثف المو اهــب : فــالكثير مــن ذوي

المواهب في الحياة المهنية و الوظيفية تم

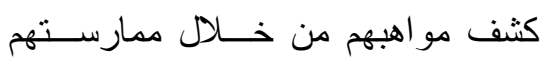

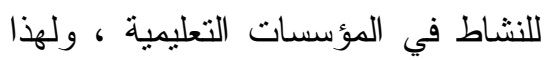

نجد الطلاب موزعين على ألوان النشاط

بينما نجدهم داخل قاعات الدر اسة غيـــر

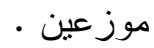

- التواصل مع المجتمع : فالنشاط هو الذي ماني

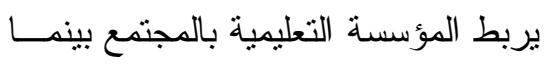

قد لا تكون المقررات الدر اسية كذلك .

r- متطلبات سوق العمل ودور الأتسشطة

$$
\text { الطلابية في تلبيتها : }
$$

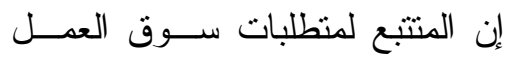

المتغير يجد أن الناحية الأكاديمية غير كافية نظر اً لمحدودية مستوى القدر ات و المهار ات

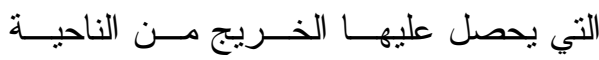
الأكاديمية و لا تلبي في الوقت نفسه احتياجات

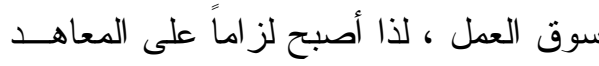

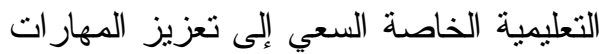

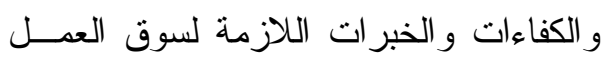

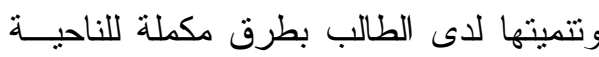

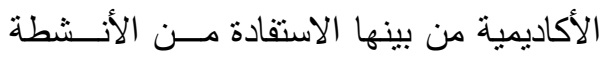

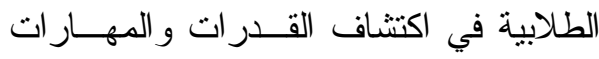

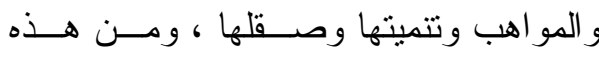

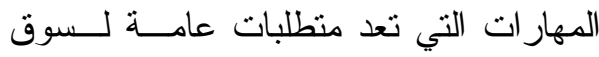

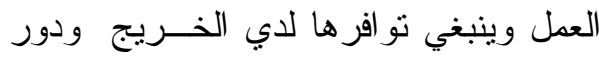
المعاهد التعليمية الخاصة في تتميتها : 
المقرر ات الدر اسية و انما أيضـا مــن خــلهل الأنشطة الطلابية ذات العلاقة بهذه المهار ات اتهنات

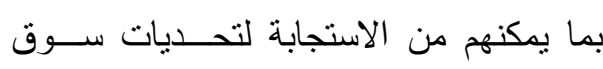
العمل. - المهار ات القيادية : ولعل في مقدمة هذه المهار ات القيادية

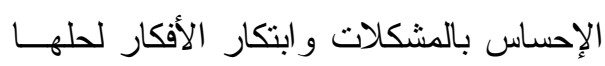

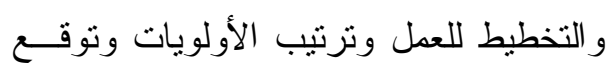

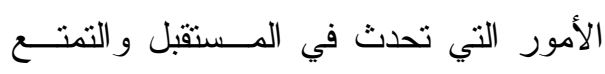
بمهار ات تصورية جيدة و القدرة على الرؤية أبعد من الوظيفة، و الوضوح و الاستعداد لنقبل التغير بالإضافة إلى القدرة على اتخاذ القرار وتحمـلـل المـسؤولية و المبــادرة و المثــابرة و الثأثثر على الاخرين والقدرة على الحــوار

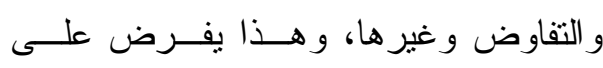

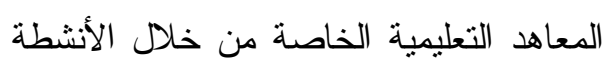
الطلابية إكساب الطلاب المهار ات القياديــة

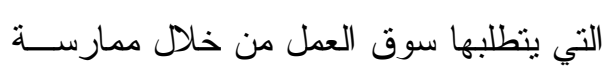

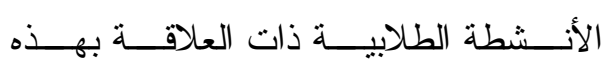

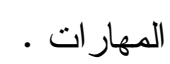

(ץ) دور التدريب التحــويلي فــي تلبيـــة متطلبات سوق العمل :

يهــتم التــدريب التحــــيلي بإعـــداد

المتدرب لتولى عمل أو وظيفــة جديــدة أو القيام بو اجبات جديدة ويهتم بإعــادة تأهيـلـل العامل الذي كان قد سبق تدريبه أو تعلم مهنة

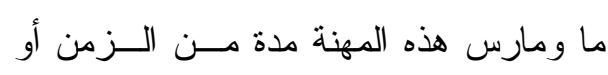

و الأنشطة الطلابية بصفة خاصــة إكــساب

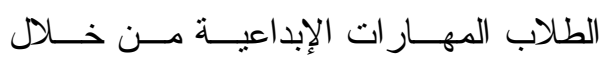
التشجيع على البحث و التجريــب و المبــادأة

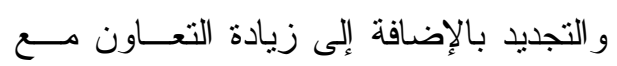

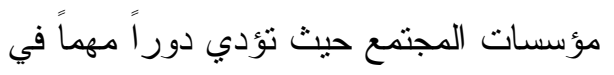

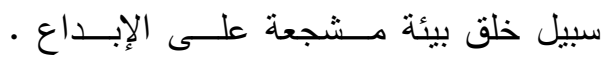

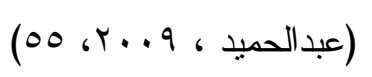
- مهارات اللغات الأجنبية : يحتاج خريج اليوم إلى إثقان مهار ات

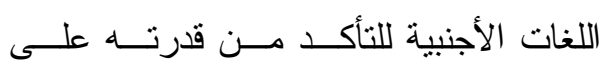

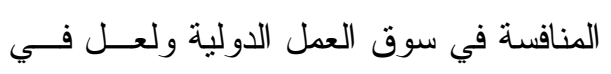

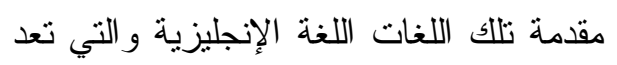

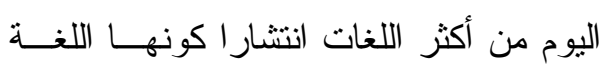

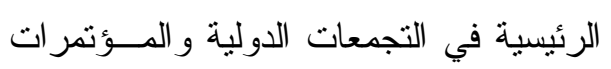
العالمية فهي لغة العلوم و التكنولوجيا و البحث

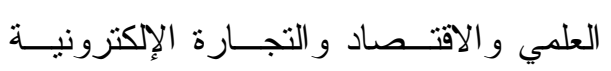
وغير ها بالإضافة إلى أنها وسيلة الاتـصال

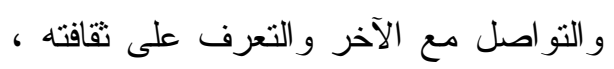

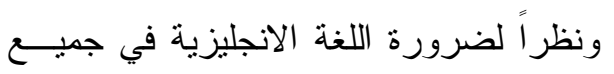

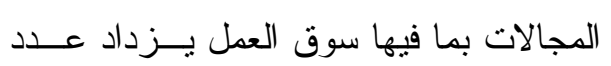

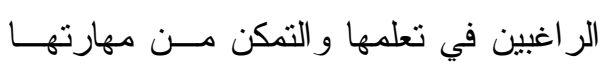

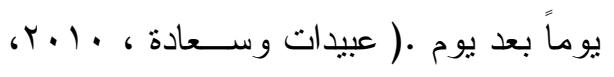

و هذا يفرض على المعاهد التعليميــة

الخاصة بصفة عامـــة و الأنسشطة الطلابيـــة بصفة خاصة إكساب الطلاب مهار ات اللغات الأجنبية بجانب اللغة الأم ليس فقط من خلال 
للمعلومات و الاتصالات و انتشار ها الـسريع

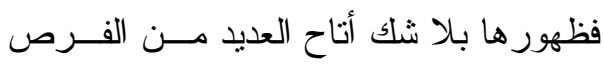

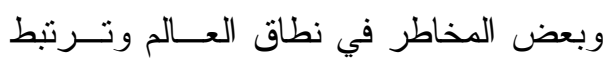

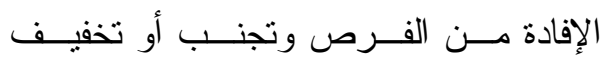

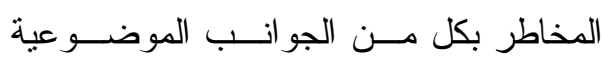

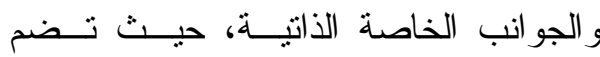
الجو انب الموضوعية توفير مصادر شــر اء

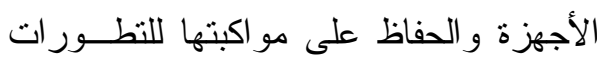
الجديدة وتدريب المتدربين على اســتخدامها

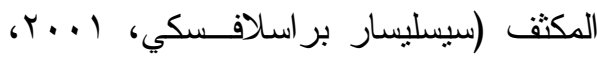
$(100$ r - ربط التعليم بسوق العمل:

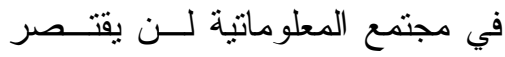

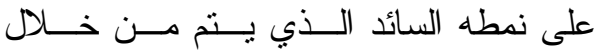

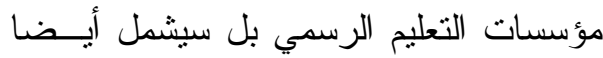

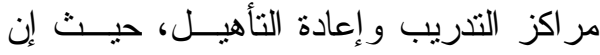
تكنولوجيا المعلومات الحديثة أصــبحت فـي طريقها إلى تحويل المصانع إلى مدر اس في

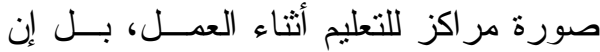
هناك مؤسسات صناعية أنسشأت جامعسـات

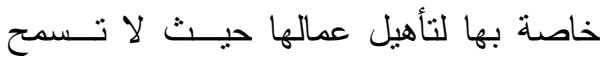
سر عة الإيقاع السريع للنشاط الإنتاجي بتقرغ

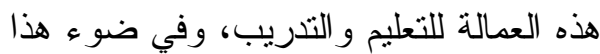

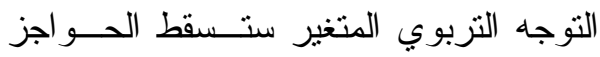

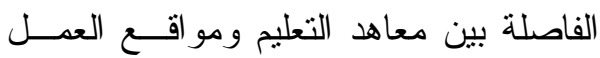

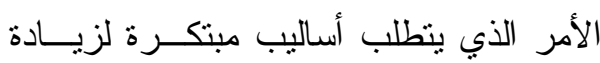

تدرب على ممارستها، ثم حدث ما يوجــب تحويله إلى مهنة أخرى غير مهنته الأصلية،

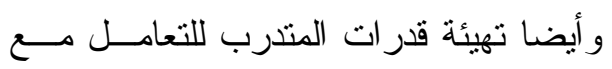
منطلبات المستقبل وتحو لاته، وفية لا تقتصر عملية التدريب على التأهيل المهني ومساعدة وله لانه

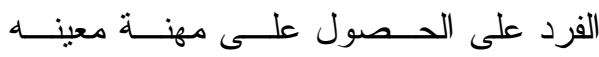

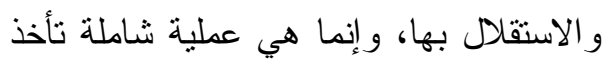

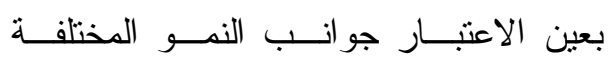
للإنسان، وتهـف إلى إعادة تـشكيل قدر اتــهـ على التكيف في مجــالات الحيــاة العمليـــة

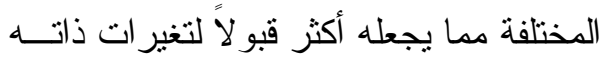
ومجنهعه.

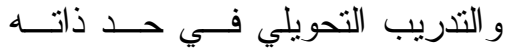
تدريب متجدد لأنه يتنبى بر امج منطورة في

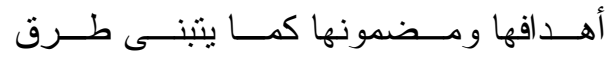
و استر اتيجيات تذريبية فلسفتها مسن العـصر الذي تتعامل معه فلكـل عـصـر منطلباتـــهـ

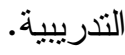

وتحدد مبررات الاهتمام بتطبيـق التـــريب التحويلي في المؤسسات التعليمية العليا في: 1- الاففجار المعرفي وثورة الاتصالات : يعد الانفجــار المعرفــي أو ثـــورة

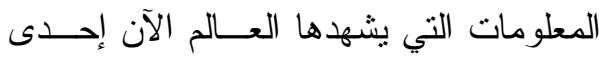

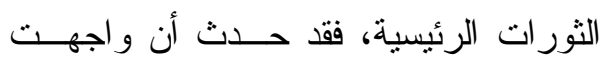

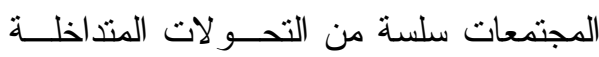

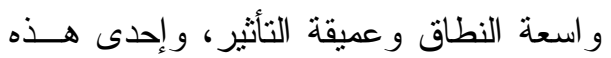

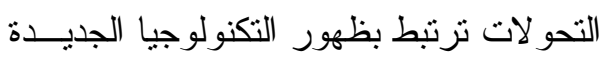


حيث ظهرت مهن ووظائف جديدة تتـسارع أهميتها يوما بعد يوم و انقرضت أخرى، كما حدث تغير في نوعية المهام و المـسؤوليات لكثير من الوظائف القائمة مما كان له أثـر واضح على الأفر اد في المجتمعات المختلفة، نتيجة لهذا التغير المنسار ع في سوق العمـلـل وما يرنبط بها من وظائف ومهن ومستويات تذفع الأفر اد باستمر ار إلى ضــرورة تغييــر وظائفهم و إكسابهم مهار ات وكفاءات جديـــدة

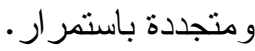

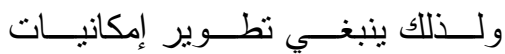
الخرجين بما يمكــنهم مــن التعامسلـ مـــع تكنولوجيا العصر ، و أمام هذا المتغيــر كــان لز اما على التربية بصفة عامة و المؤســسات التعليمية بصفة خاصة أن تمنلك القدرة على استثمار التكنولوجيا الجيدة وأدواتها المعرفية في إثزاء العملية التعليمية سواء من خــلاله تقديم الخبرات التكنولوجية لتطوير المنــاهـ

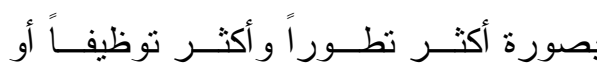
استخدامها كثقنية مساعدة في تقديم خبــرات المو اد الدر اسية المختلفة. 0- التطور في تكنولوجيا التعليم:

اكتسبت تكنولوجيا التعلــــم أهميـــة

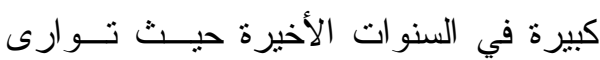
مفهوم الوسائل التعليمية بــصورته التقليديــة و اندمجت تكنولوجيا التعليم الجديدة مع نظــــ التعليم وطر ائقه، ومما ساعد في دعــم دور
فاعلية أسلوب التعليم بما بتتاسب ومنطلبــات سوق العمل (على، I. . . ب، 0 1ب). r- الاتتقال من التخلف إلى التنمية: حيث تعني التتمية عمليــة مـسنتمرة طويلة الأجل ، تمر بمر احل متعددة وتقتضي تغيير اً في السياسات و الأولويات من مرحلـــة لأخرى، ولكنها تغييــر ات لا تتحقــق إلا إذا كان قو امها ترسيخ نظام القيم و الأخلاقيــات

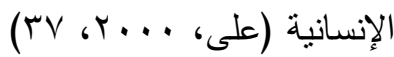
إن عملية التتمية هي عملية شمولية تتطلــب إثر الك جميع الأفراد في عملية التتمية إلا أن ذلك بيطلب نتصبر هم بالمهام التـي أســنـهـا إلبهم المجتمع. ع - التغير في طبيعة المهن والوظائف :

أحدثت الثورة العلمية و التكنولوجيــة تغير ات متسار عة في عالم العمــل ســــاعدت بدرجة كبيرة على تغير هيكل الطلب علـى المهار ات المتطلب توفر ها بالعامل، ذلــــ أن هيت الكثير من العمليات كانت تــتم بــدويا فــي الماضي وأصبحت في الوقت الحالي آليــة، كما أن الطلب على بعض المهار ات اليدويـــة قد اختفى، وحلت محلهــــا مهـــار ات جديـــدة تنتاسب وطبيعة العصر التكنولوجية و العلمية المتسار عة. (عوض،

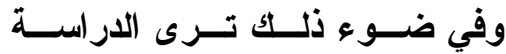
ضرورة الاعتماد على التــدريب التحــــيلي ليواجه التغير الحاصل في المهن و الوظائف، 
النوعية والحاجة الفعلية لسوق العمل ومن

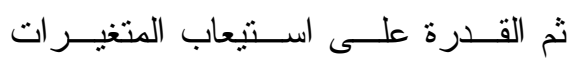
المحيطة. - تتأثز منظومة التعليم العالي كغير ها مــن

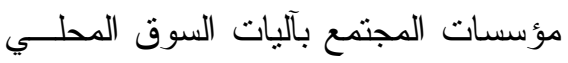

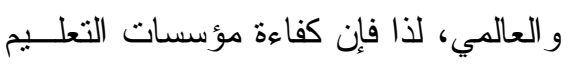
العالي اليوم أصبحت تقاس من خلال مدى كلى مؤسنان تقارب وتلائم مخرجاتها مع السوق.

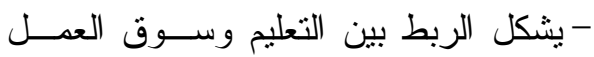

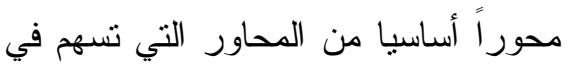
تتمية الموارد البشرية وفي تطوير اقتصاد أي دولة، فبقدر ما يكــون الــربط بــين التعليم وسق العهـل ناجحــاً ومنطــــوراً

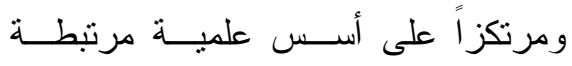

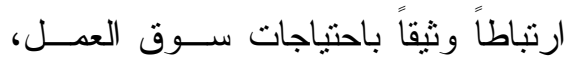

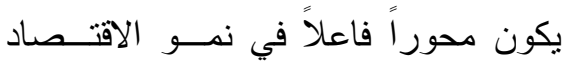
الوطني القومي و ازدهار ها. - يهذف الربط بين التعليم وســـوق العدــل بالمهن المختلفة إلى ما يلي:1- ربط التعليم وسوق العمل بخطط التتمية الاقتصادية. r- إعداد الأيدي الماهرة في شتى الهن المجالات وتأهيلها للإسهام في خطط النتمية. r- العمل على تأهيل الطلاب و المتنربين وفق قدر اتهم وميولهم تهيل
تكنولوجيا التعليم في العمليــة التعليميـــة لأن

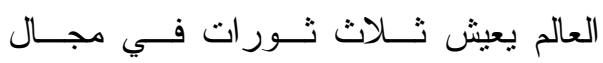
تكنولوجيا المعلومات وهي:

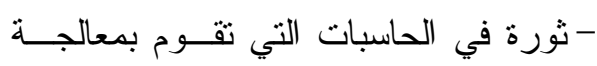
المعلومات بشتى الطرق وبـسر عة تكــــاد تكون فورية وبدقة متتاهية.

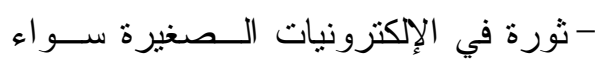
أكانت في الأجهزة أو في قدرة الأجهــزة

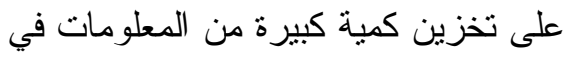
حيز صغير -ثورة الاتصـالات و استخدامها فــي مجــال التعليم و الإعلام. وكلما زاد الفرد من حسصيلته فـي مجال تخصصه بالحقائق التي أوضحها العالم حديثاً، و الممارسات و التجارب التي حـدثت بـث في هذا الميدان، كلما زادت إنتاجيته الفكرية

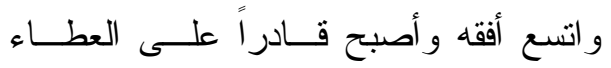

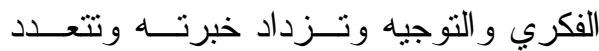

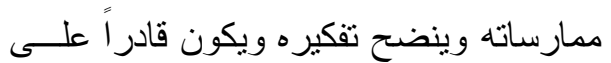

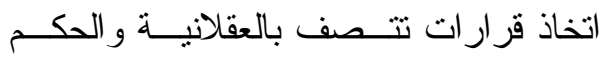

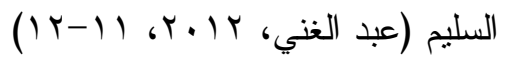
النتائج والمقتزحات : أولا: النتائج: - أصبحت منطلبات سوف العمل منطلبــات أنسات

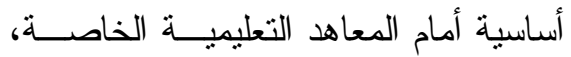
الأمر الذي يتطلب ديناميكية سريعة فـي الفي رسم الخطط المستقبلية لتضيق الفجوة بين 
الأساتذة الجامعيين ، كما يتطلب مو اكبــة

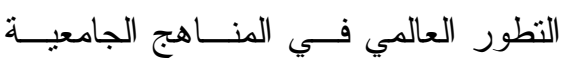
وكيفية تتفيذ محتو اها مع الطلبة .

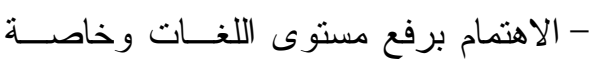
اللغة الانجليزية لدى الخــريجين ، كـــــاس يجب ربط القبول فـــي الكليــات العلميــة بمعايير إقليمية أو عالمية في مجال اللغة .

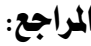

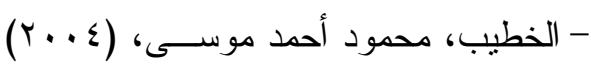
التخطيط الاســتراتيجي فـــي مؤســــات

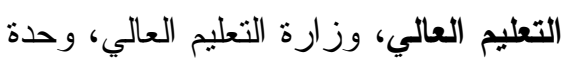

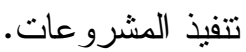

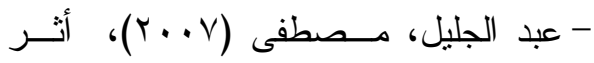

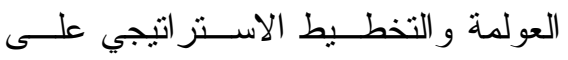

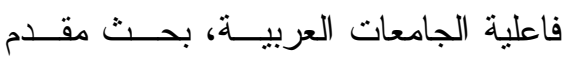

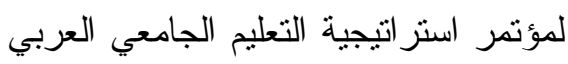

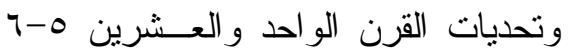
ابريل، 91 (9)

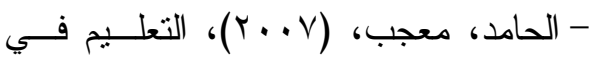
المملكة العربية السعودية رؤية الحاضــر و واستشر اف المستقبل، الرياض : مكتبــة

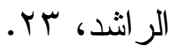

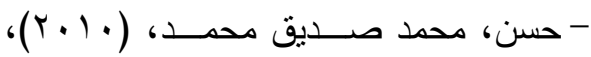
التعليم العالي في الوطن العربي ومنطلبات سوق العمل، مجلة التربية القطرية، العدد

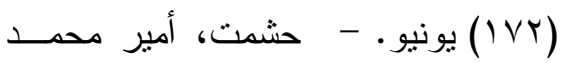

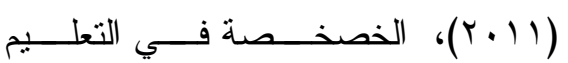

- أن تهنم إدارة المعاهد التعليمية الخاصـــة بالأنشطة الثقافية والاجنماعية و الفنية التي

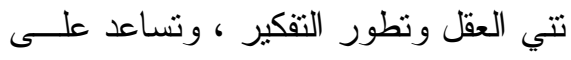
الاهتمام بنقافة المجتمـــع وتــساعد علــى اكتـششاف مو اهـــب الطـــلاب وقــــــر اتهم ومهار اتهم وصقلها وتشجيعها ـ

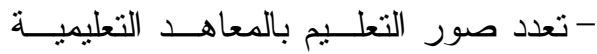
الخاصة لإتاحته لجميع الأفراد في أثنكاله المختلفة من تعليم مفتوح وتعليم عن بعـد لإليد

$$
\text { وتعليم مدى الحياة . }
$$

- الرعاية المـــتمرة للطــلاب المبــدعين و المبتكرين بالمعاهد التعليميــة الخاصـــة

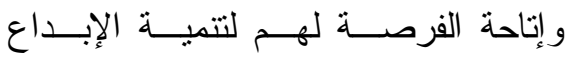

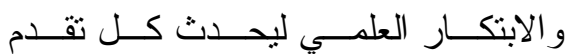

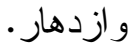
- على المعاهد التعليمية الخاصة أن تحرص

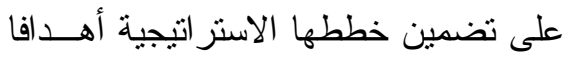

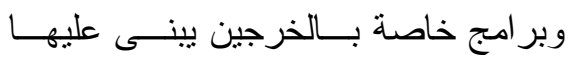
تحديد مسنوى قبول الطلبة كمّا ونوعا بما

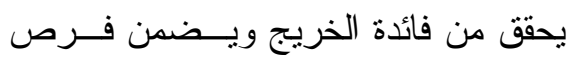
عمل لائقة في السوق المحلي أو الإقليمي أو العالمي. - يجب أن تطور المعاهد التعليمية الخاصـــة مخرجاتها في بُعديها المعرفي و المهــاري

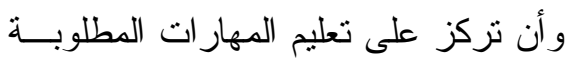
بسوق العمل ، و هذا بتطلب تطــــــر أداء 


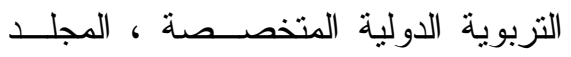

$$
\text { الثاني ، العدد الثاني عشر • }
$$

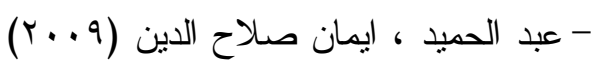
، تطوير البرامج الدراسية الجامعية فــي الئل

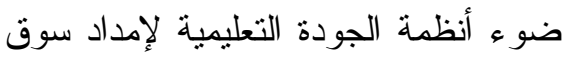

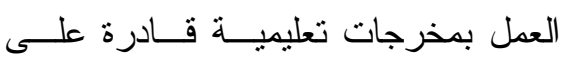
مو اجهة التحــديات العالميـــة ، المـــؤتمر السنوي (الدولي الاول - العربي الرابع )

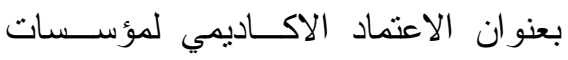
وبر امج التعليم العالي النوعي في مــصر العرد

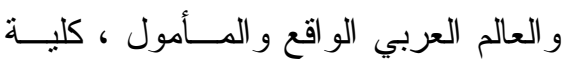
التربية النوعية ،1-1 إبريل.

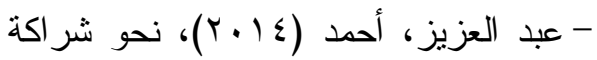
حقيقية بين الجامعة و المجتمع، المـــؤتمر

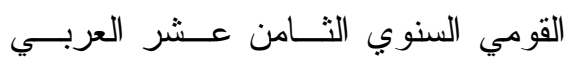
العاشر بعنوان تطوير منظومة الاداء فــي الـي الجامعات المصرية في ضوء المتغيــرات العالمية، · 1-11 أغسطس.

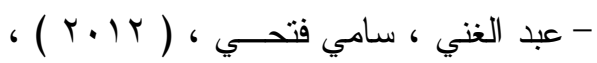
تصور مقترح لتفعيل العلاقة بين التعلــيم الفني وسوق العمل في مصر في ضــوء تجارب بعض الدول المنقدمـــة ، مجلـــة مستقبل التزبية العربية ، المجلــــــالتـــع عشر ،، العدد .1 . - عبيدات ، اسامة محمد وسعادة ، ســائدة

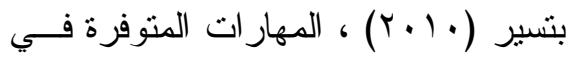

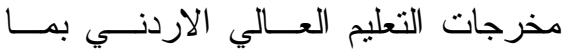

الجامعي ومتطلبات سوق العمل، رســالة

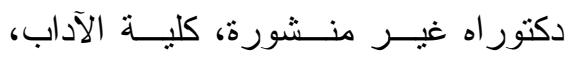
جامعة عين شمس.

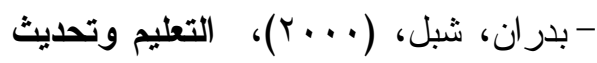
المجتمع، القاهرة : دار البقاء.

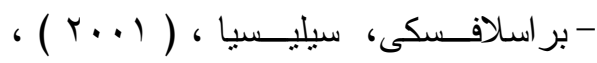

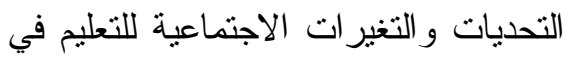
القرن الحادي و العشرين" ، ترجمة زينــبـ

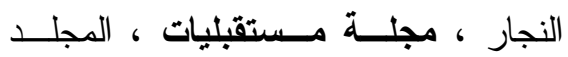

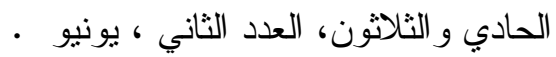

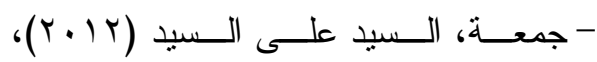
الشر اكة بين الجامعة ومؤسسات المجتمع كاتجاه لتطوير التعليم الجامعي، مجلة كلية التربية بالسويس، المجلد الخامس، العـدد

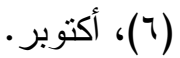
- حسن، عبد المــنعم الدســوقي، (10 • ب)، مشكلات المعاهد العليا الخاصة بجمهورية مصر العربية - دراسة ميدانيــة، مجلـــة الادارة التربويــة - الجمعيــة الـــصرية للتربية المقارنة والادارة التعليمية، المجلا الثاني، العدد السادس، سبتمبر •

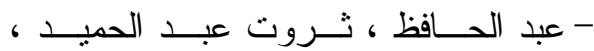

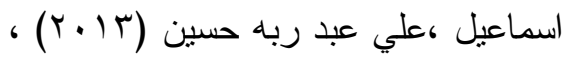
تطوير ادارة الاتشطة الطلابيــة بجامعــة المنصورة للمواءمة بين مخرجات التعليم الجامعي ومتطلبات سوق العمل ، المجلــــة 
الخبرة الكوريـــة، مجلـــة كليـــة التزبيــــة

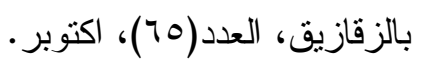

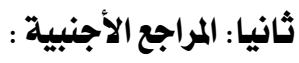

- Dhillon,jaswinder (2007) : Trust,shared Coal and Participation in partnerships: reflection of post-16 education and training providers in England ,Journal of vocational education and training ,Vo (59),No (4).

- Hughes, jeffryand others(2006) :" The task force on intial teachers education programs ", Final report, Manitoba university Winnipeg.

- Lunenburg,fred Exacurricu lar Activities, Schooling, Vo (1), No (1)

- Marphy,Karen:Richards,Judith,( 2005):Strengthening Educational Technology in K-8 Urban schools and in presevice Teacher education :A practitioner Faculty collaborative process, journal of Technology, Vo (13), No (1).

- Yingxia.G ,(2000) priate Higher Education and the labor market in China institutional management Efforts and Initial employment out comes ph.d.state University of new yourk.

$$
\begin{aligned}
& \text { يتطلبه سوق العدــل المحلـــي ، المجلـــة }
\end{aligned}
$$

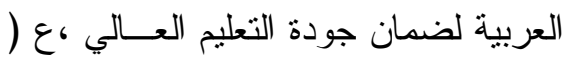

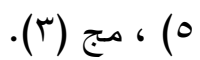

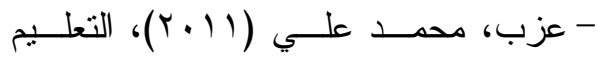

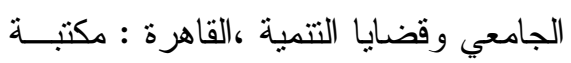

$$
\begin{aligned}
& \text { الانجلو المصرية، سبا. }
\end{aligned}
$$

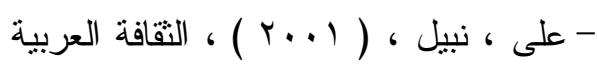

$$
\begin{aligned}
& \text { وعصر المعلومات ، الكويــت : عــالم } \\
& \text { المعرفة - المجلس الوطني للفنون و الثقافة }
\end{aligned}
$$

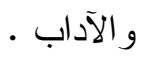

$$
\begin{aligned}
& \text { - فيحان، صباح محمود ومسشعل ، فــائق }
\end{aligned}
$$

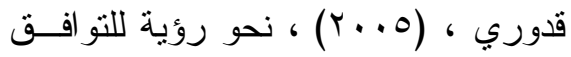

$$
\begin{aligned}
& \text { بين مواصفات الخريج وسوق العــلـل - } \\
& \text { حالة در اسية في التخصــصـات الاداريــة } \\
& \text { و الاقتصادية ، الـــؤتمر العربــي الاول } \\
& \text { بعنوان استشر اف مستقبل التعليم - التعليم } \\
& \text { العالي العام - التعليم التقني في الفترة من }
\end{aligned}
$$

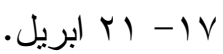

$$
\begin{aligned}
& \text { - الموسوعة العربية العالمية ، ( } 1991) \text { ( العيل. } \\
& \text { الرياض : مؤسسة أعمال للنشر و التوزيع }
\end{aligned}
$$

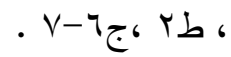

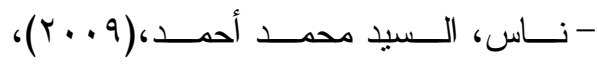

$$
\begin{aligned}
& \text { الثر اكة بين التعلـيم و التــدريب وســـوق } \\
& \text { العمل : در اسة للو اقع المصري في ضو وله }
\end{aligned}
$$

